\title{
Black Americana: supremacia racial e supremacia de classe em fotografias da virada do século XIX ao XX
}

\author{
Black Americana. Racial supremacy and class supremacy in \\ photographs from the turn of the 19th to the 20th century
}

\section{Antonio Luigi Negro*}

Resumo: Este artigo analisa o papel desempenhado pela produção e circulação de imagens fotográficas em cartões postais durante o processo de reconciliação nacional entre as supremacias de raça e classe, na sociedade estadunidense do pósabolição, a partir da década de 1880. Somado ao trabalho por dívida, o aluguel de detentos do sistema prisional aponta para a recomposição da prática de obrigar proletários negros ao trabalho, fenômeno que teve lugar especialmente onde a escravidão mais resistiu ao abolicionismo, isto é, não apenas no Sul, mas sobretudo na lavoura (ou em atividades a ela ligadas, a exemplo das ferrovias). Nesse sentido, para os trabalhadores, as lutas entre capital e trabalho podiam ter no direito de ir e vir um elemento essencial de sua experiência de classe.

Palavras-chave: Galés; linchamento; cartão postal; trabalho.

Abstract: This article analyzes the role played by the production and circulation of photographic images in postcards in the process of national reconciliation between race and class supremacy in post-abolition American society, from the 1880s onwards. In addition to indebted labor, leasing inmates had a relevant part in the restoration of the practice of black proletarians forced to labor, a phenomenon that took place especially where slavery most resisted to abolitionism, not only in the South, but in the plantation system in particular (or linked activities such as railways). In this sense, to workers, the right to mobility was an essential element of their class experience.

Keywords: Chain gang; lynching; postcard; labor. 


\section{Introdução}

Como será aqui tratada, a escravidão (conforme definição de Genovese) é um "sistema de dominação de classe", de subordinação de "uma raça à outra". Peter Eisenberg, em livro sobre a Guerra Civil Americana, desvenda como uma aliança entre comerciantes e proprietários de terra (não necessariamente fazendeiros) buscou sufocar, com lavoura de algodão, a aspiração de autonomia social e de independência econômica dos trabalhadores negros no pós-abolição. Para estes, afora a cotonicultura, plantar comida, cevar animais, e compra-e-venda com dinheiro vivo no mercado livre, eram termos básicos de sua experiência e planos para o futuro. Eisenberg elucida como, de modo contrário aos seus planos, os trabalhadores agrícolas se tornaram ainda mais dependentes do crédito fornecido por vendeiros. Como credor, na hora de receber, o comércio estabelecia sua expectativa de ver dívidas quitadas em fardos de algodão, e não em dinheiro, exatamente o que os trabalhadores preferiam dispor com a venda de suas colheitas. Produzindo mais algodão para honrar débitos e, consequentemente, com menos alimentos colhidos, o preço dos gêneros alimentícios aumentou e quem passou a revender ainda mais comida (com lucro ainda maior) foi o mesmo armazém onde dívidas eram penduradas pelas famílias negras, que eram pequenos produtores. Com algodão recebido dos pagadores de seus débitos, a mercadoria, por ser facilmente estocável, podia esperar a oportunidade de ser vendida na hora certa. A aliança dos comerciantes com os proprietários de terras estava dada, por fim, pelo interesse de ambos de não verem trabalhadores agrícolas prosperarem como pequenos produtores aspirantes à propriedade de terras. Outro interesse coincidente entre os dois era o de botar os agricultores na posição de trabalho por dívida. Em suas mãos brancas - comércio e propriedade -, os trabalhadores negros eram, com o passar do tempo, embolados numa relação que lhes era prejudicial. ${ }^{1}$

Mesmo assim, para preservar a supremacia racial e de classe, outros dispositivos tiveram de ser bem mantidos. ${ }^{2}$ Não bastou o assédio moral segundo o qual os brancos eram bem-sucedidos porque tinham mérito, e que famílias negras

GENOVESE, Eugene. A terra prometida: O mundo que os escravos criaram. Rio de Janeiro: Paz e Terra, 1988. p. 21. EISENBERG, Peter. Guerra civil americana. São Paulo: Brasiliense, 1982. p. 96 et seq.

Apesar das críticas a Genovese, não se deve negligenciar a avaliação de ter apresentado "quadro novo do Sul escravista". CUNHA, Manuela C. da. Negros estrangeiros: os escravos libertos e sua volta à África. São Paulo: Companhia das Letras, 2012. p. 92.

2 LICHTENSTEIN, Alex. Twice the work of free labor: The political economy of convict labor in the New South. Londres: Verso, 1996. BLACKMON, Douglas. Slavery by another name. The reenslavement of Black Americans from the Civil War to World War II. Nova lorque: Doubleday, 2008. 
de pequenos produtores fracassavam porque eram racialmente inferiores. Fontes inéditas disponíveis nas nuvens da rede www - em bases arquivísticas ou à venda permitem ver outras linhas de nítida demarcação da supremacia de classe e racial dos brancos sobre os negros, na sociedade estadunidense do pós-abolição. Neste artigo, veremos item de grande circulação - o cartão postal - no seu próprio tempo de edição e consumo (e agora de revenda), parte minúscula do universo designado Black Americana. Cartões comemorativos de linchamentos de homens negros são mais comuns e já foram estudados. Aqui, irei me deter nos (mais raros) cartões de galés, chain gangs, grupos de trabalhadores - comumente negros - acorrentados porque detentos do sistema prisional e forçados ao trabalho, por exemplo, na lavoura ou em estradas de ferro. Parafraseando Roxanne Dunbar-Ortiz, esta fonte é reflexo da Constituição estadunidense, consistindo ela também em texto minúsculo e "sagrado da religião cívica que é o nacionalismo estadunidense", expresso na segunda emenda, a que franqueia o direito do porte de armas. Quer a carta constitucional, quer o cartão postal aqui em tela, estão "inexoravelmente" atrelados "à supremacia branca". 3

Antes de prosseguir, indico que este artigo almeja a dar continuidade à "especial ênfase da historiografia brasileira em combinar História da escravidão e história do trabalho 'livre'", conforme Weinstein percebeu e registrou. ${ }^{4}$ A mesma autora acrescenta que também em seu país "a tendência historiográfica de maior influência" é a "que pensa no 'mundo do trabalho' de uma maneira bem ampliada e, portanto, que incorpora plenamente 'trabalhadores' de todo tipo, inclusive trabalhadores escravizados". Referindo-se à - legal ou ilegal - "falta de liberdade da força de trabalho", Julius Scott observa que trabalhadores chamados de "livres"” podem ser mais "anomalia" do que "regra". E, então, assim como a ferrovia britânica, na Bahia da década de 1860, não fez questão de discernir se os trabalhadores negros eram livres ou escravizados, as ferrovias construídas por trabalhadores negros nos Estados Unidos não se indagavam se eram homens livres ou cidadãos de segunda classe, ou ainda uma nova forma de escravizados, inventada para quase que suceder o fim da escravidão. ${ }^{5}$

3 DUNBAR-ORTIZ, Roxanne. Loaded: A disarming history of the second amendment. San Francisco: City Lights Books, 2018. Ver também: ONKEN, Hinnerk. Visiones y visualizaciones: la nación en tarjetas postales sudamericanas a fines del siglo XIX y comienzos del siglo XX. Iberoamericana, $\mathrm{n}^{\circ}$ 56, 2014. OSTLER, Jeffrey. Surviving Genocide: Native Nations and the United States from the American Revolution to Bleeding Kansas. New Haven: Yale University Press, 2019.

4 WEINSTEIN, Barbara. Globalizando a história do trabalho: o caso da revista International Labor and Working-Class History. Mundos do Trabalho, v. 9, n 18, 2017. p. 18.

5 SCOTT, Julius. Common wind: Afro-american organization in the revolution against slavery. London: Verso, 2018. p. 2, 3. SOUZA, Robério. Trabalhadores dos trilhos: imigrantes e nacionais livres, libertos e escravos na construção da primeira ferrovia baiana (1858-1863). Campinas: Editora 
Pode-se inclusive dizer que o papelãozinho carimbado nos correios embarcara no trem. Uma vez percebido como produto de crescente mercado consumidor, era possível comprar e remeter um bilhete postal de dentro de vagão ou navio, chance (diga-se) que não era disponível a qualquer um. No século XIX, "a forma característica de viagem para o pobre era a migração", ensina Hobsbawm. Já "para a classe média e os ricos", consistia mais e mais em turismo, o qual era "um produto da estrada de ferro, do barco a vapor e [...] da nova magnitude e rapidez das comunicações postais", das quais o cartão postal era não só uma "invenção" mas também "uma parte essencial". De fato, depois de 1869, quando as comunicações postais foram "sistematizadas internacionalmente com o estabelecimento da International Postal Union", o bilhete ou cartão postal se tornou uma coqueluche global. ${ }^{6}$

\section{Bilhete ou cartão postal}

Sucessor da geração imediatamente anterior (o bilhete postal) e de outra geração mais provecta (dividida pelo menos em dois grandes grupos: a carte-devisite e a carte cabinet), afora a geringonça da estereoscopia, o cartão postal é resultante da fusão do bilhete postal com a carte-de-visite ou cabinet. Do bilhete herdou o nome (usado em paralelo a cartão) e, além disso, também herdou as características do pequeno tamanho, de ser prático e expresso, seja para redigir, seja para postar nos correios, sendo prático também para receber, ler e manusear. No entanto, o cartão era uma correspondência aberta e, basicamente, imagética. Já o bilhete era fechado e, fundamentalmente, textual. A carte-de-visite ou a cabinet transmitiu ao cartão postal a composição da imagem fotográfica, que passou a ser um impresso. Devido à falta de (ou ao pouco) espaço para escrever, também legou ao cartão o tom de história íntima, encurtada em poucas palavras.

É importante notar que o cartão foi produzido de diversas maneiras. Quando deixou de ser uma prerrogativa exclusiva dos correios e virou mercadoria de gráficas particulares, a imagem (na forma de desenho, pintura, fotografia, gravura etc.) logo foi impressa para atrair a atenção e vender milhares de exemplares, milhões de bilhetes. Bilhete e cartão, nesse instante, passaram a significar a mesma coisa que, por sua vez, podia ter ou não um espaço exclusivo e reservado à escrita de uma mensagem textual. Quando isto não ocorria, os remetentes se calavam ou criavam

da Unicamp, 2015. p. 75-112. Sobre a construção da ferrovia de ligação entre o litoral paulista e a Bolívia, ver: MORATELLI, Thiago. Operários de empreitada: os trabalhadores da construção da estrada de ferro Noroeste do Brasil (São Paulo e Mato Grosso, 1905-1914). Campinas: Editora da Unicamp, 2013.

6 HOBSBAWM, Eric. A era do capital: 1848-1875. Rio de Janeiro: Paz e Terra, 1982. p. 216. 
lugares para se exprimir. Com o passar do tempo, a mercadoria ficou sofisticada. Podia ter uma textura mais cara que o simples papelão. Ou podia ser uma fotografia, com um papel colado no verso, indicador da marca do filme. Ao contrário do bilhete postal, o cartão (tal qual a carte-de-visite) podia ser disposto em séries e encadernado em álbuns pelos estúdios fotográficos, em pequenas ou grandes cidades do mundo. Quer dizer, podia ser algo corriqueiro ou podia ser diferenciado, sobretudo quando objeto de coleção ou presente. Com cartões, era possível viajar o mundo sem sair de casa.

Parte dessa viagem era lúgubre e nostálgica volta ao passado. Sem expectativas de espelhar mudanças na justaposição entre supremacia racial e de classe, o cartão postal reflete as polarizações da sociedade estadunidense, tanto a Guerra Civil da década de 1860, quanto, mais abrangentemente, o genocídio e a (re)escravização, sendo sua superfície espelho para o contentamento daqueles homens e mulheres favoráveis à conservação das hierarquias apontadas até aqui. ${ }^{7}$ Invenção do final do século XIX, o bilhete ou cartão postal acompanhou a repartição do mundo do ângulo de "um pequeno número de Estados" - impérios -, "a expressão mais espetacular da crescente divisão do planeta em fortes e fracos, em 'avançados' e 'atrasados"'. ${ }^{8}$ Hobsbawm também observa a tendência de "uma economia mundial cujo ritmo era determinado por seu núcleo capitalista desenvolvido", impulsionada por ordem global "onde os 'avançados' dominariam os 'atrasados'”. Em boa medida, o postal era a imagem e semelhança dessa hierarquia entre impérios e colônias, entre civilizados e selvagens, entre burgueses e proletários.

Como fonte, o cartão é prova da supracitada "principal tendência na historiografia do trabalho escravo nos Estados Unidos hoje", exatamente por esclarecer que "não há nenhuma contradição entre capitalismo e trabalho escravo". Antes, pelo contrário, capitalismo e escravidão são par amoroso de história global, adocicada por cartões afetuosos:

\begin{abstract}
"o trabalho forçado é conceituado como um aspecto recorrente e permanente do sistema capitalista, e a economia escravista do sul dos Estados Unidos é vista como a locomotiva da expansão econômica do país inteiro e um estímulo principal para inovações tecnológicas; e mais, um elemento fundamental na globalização do capitalismo". ${ }^{9}$
\end{abstract}

O apelo de certas mídias e, no interior do conjunto Black Americana, o interesse despertado por certos elementos particulares, ativaram e alimentaram coleções,

\footnotetext{
THOMPSON, K. T. Stock Histories. Social Text, v. 37, nº 1, 2019.

HOBSBAWM, Eric J. A era dos impérios: 1875-1914. São Paulo: Paz e Terra, 1988. p. 91, 87.

WEINSTEIN. op. cit., p. 19.
} 
primeiramente montadas como uma coisa da vida privada, o que, posteriormente, veio a animar, ou a sua curadoria em arquivos, ou o seu comércio de compra e revenda (com farta digitalização para o anúncio comercial na rede WWW). ${ }^{10}$ São itens mantidos com zelo, no privado por colecionadores, em gabinetes por cientistas, ou em coleções de arquivos, mas também comprados e revendidos no comércio de antiguidades. Datados entre o fim do século XIX e o início do XX, os cartões postais de linchamentos e de negros acorrentados, nos Estados Unidos, são uma parte alarmante da memorabilia Black Americana. ${ }^{11}$ Ainda mais antigos mas - bem recentemente - muito mais polêmicos, são dois daguerreótipos encomendados a um retratista da Carolina do Sul na década de 1850, fotógrafo do africano escravizado Renty e de sua filha Delia. Ambos, mandados a se despir, tiveram suas imagens, tiradas de vários ângulos, usadas pelo professor de Harvard Louis Agassiz, a fim de sustentar a ideologia do racismo científico. Segundo, Garrison, elas são "cruas e desumanizadoras". ${ }^{2}$ Isso não deixa de lembrar a volta dos que não foram (ou o passado que não passa): dado o fato de o trabalho braçal na lavoura consistir no último serviço a ser franqueado a seres livres, não surpreende - embora seja chocante - o esforço de reimplantar, ante a vigência da liberdade dos negros, o trabalho forçado no mesmo chão que, com grande cautela e demora, havia sido reservado para o fim do fim do desmonte lento, gradual e seguro do escravismo. O que antes era o fim do fim passou a ser a arena primária da luta de classes no pós-abolição.

\section{Linchamentos}

No Brasil, os cartões postais de linchamentos de homens negros talvez tenham sido mencionados pela primeira vez em estudo histórico por Robert Slenes. Tendo em vista imagens fotográficas de duas mulheres baianas, indexadas nas letras $D$. e K., Slenes aborda parte de uma série postal produzida e vendida por Lindemann, na Bahia do início do século XX. Ao deixar de lado as particularidades técnicas, tanto

10 BAKER, Stacey; MOTLEY, Carol; HENDERSON, Geraldine. From despicable to collectivle: The evolution of collective memories for and the value of black advertising memorabilia. Journal of Advertising, v. 33, n 3, 2004.

11 Para um exemplo do debate que o tema pode causar, ver: CASMIER-PAZ, Lynn. Heritage, not Hate? Collecting Black Memorabilia. Southern Cultures, v. 9, $n^{\circ}$ 1, 2003. Apenas sobre postais, ver: MASHBURN, J. L. Black Americana postcard price guide: A century of history preserved on postcards. Enka: Colonial House, 1996.

12 GARRIOSN, Joey. Harvard University sued over allegedly profiting from what are believed to be the earliest photos of American slaves. USA Today, MacLean, 20 mar. 2019. Disponível em: https://www.usatoday.com/story/news/nation/2019/03/20/harvard-university-sued-descendantsslaves-over-photos-renty/3213537002/. Acesso em: 23 abr. 2019. Fica também aqui o registro da intervenção de Robério Souza, no IV Seminário Internacional Mundos do Trabalho, realizado na UFAM em 2016. Souza chamou a atenção, exatamente, para a sensibilidade que se tem de ter com tais tipos de imagem. 
da arte fotográfica, quanto da edição gráfica, ele examina os textos do remetente Dico, nome usado na assinatura de ambas as correspondências. Lendo-as, vale notar, Slenes teve a fotografia delas em mente todo o tempo. "Enviando-te esta linda crioula (não vás ficar apaixonado)", ele cita e situa: "é assim que um brasileiro provavelmente um branco da elite paulista - se dirige a um amigo". O autor esquadrinha a fonte como um texto e repara: "a palavra 'saudades', escrita pelo correspondente no turbante da mulher, contribui para a insinuação erótica". E mais: já que as saudades estão na cabeça dela, era a “'crioula' (negra nascida no Brasil), não ele", Dico, quem "mais sente a falta do amigo". "A brincadeira permite-nos flagrar", afirma, "um micromomento na invenção de uma tradição 'positiva'” sobre a baiana afrodescendente. Por outro lado, o chiste "retrata fato mais sombrio", concernente a "sociedades escravistas: a transformação da mulher de cor no objeto sexual mais cobiçado do homem dominante". ${ }^{13}$ Dico portanto tem o poder de despachar "linda crioula" ao amigo de Curitiba e o fez pelo menos duas vezes.

Em nota, Slenes recupera o texto acompanhante de K., "crioula". "Faz a mesma brincadeira", sintetiza. O remetente Dico apela a texto quase idêntico: "enviando-te esta linda crioula como presente", acusa ter recebido votos de boas festas e protesta feliz ano novo, no idioma alemão (o desejo abusivo e estrangeirismo, ambas coisas de civilizados). Slenes continua a inquirir o postal, superfície simbiótica para texto do indivíduo desenvolver-se sobre a imagem reproduzida em série. E então ele aponta para a produção de retratos utilizada nos postais celebrativos de linchamentos de homens negros nos Estados Unidos, "gênero de grande aceitação" entre os consumidores. Slenes faz em seguida fina leitura do texto de um remetente que comemora - isto mesmo - o "churrasco" de um homem negro assassinado e queimado, em linchamento pela multidão branca racista. ${ }^{14}$ Fica escancarada a sedução da imagem sobre o comprador do cartão e também quanto o ato de escrever dá vazão à energia da atração sentida.

"Este é o churrasco do qual participamos ontem à noite meu retrato está à esquerda com uma cruz em cima", escreveu Joe. "É assim", aponta Slenes, que um filho se dirige ao pai, em 1916. Esse remetente, diferentemente de Dico, devia ser um jovem da classe trabalhadora, pois é desse modo que ele é notado em meio à turba fotografada no retrato usado em postal comemorativo de um crime hediondo, sinistro e coletivo. Conforme citação feita, este e outros postais compõem a

13 SLENES, Robert. Prefácio. In: GOMES, Tiago. Um espelho no palco: identidades sociais e massificação da cultura no teatro de revista dos anos 1920. Campinas: Editora da Unicamp, 2004. p. 15,16 .

14 Ibidem, p. 16. 
exposição e o livro de James Allen, Without a sanctuary. Além dessa menção, Slenes trama o texto dos postais à letra autobiográfica de Gilberto Freyre. Este, jovem, em 1919, na cidade de Waxahachie (Texas), presenciou atrocidade semelhante "e soube de outras, não nomeadas". Ao aludir como a mobilização política de associações afrodescendentes "manteve a questão na manchete dos grandes jornais e na agenda dos intelectuais", Slenes cogita que Freyre, durante a pós-graduação em Columbia e, ainda, em outro estágio nos EUA em 1931, teria em mente os linchamentos para elaborar a "oposição" que marcou Casa-Grande \& Senzala. Para Slenes, sua comparação de "sistemas de relações raciais" entre Brasil e Estados Unidos deveu muito ao que refletiu sobre a prática terrorista dos linchamentos. ${ }^{15}$

Tal como serviam a colecionadores de tipos humanos e de costumes locais que com suas coleções se faziam às vezes de cientista em Harvard -, os postais de linchamentos eram um lugar de memória onde seus consumidores não só escreviam textos como também faziam marcações esclarecedoras a respeito de quem estava onde em tal momento do homicídio. O gozo da supremacia branca fazia o racismo levitar impune, nas asas do postcard. Essas pequenas superfícies de papel constituíam, por isso mesmo, uma segunda fase celebrativa, posterior à rapina que faziam os psicopatas envolvidos em atos de assalto e tortura, seguidos pela morte da vítima, com vilipêndio de cadáver. Desejosos de eternizar e não esquecer, produzindo relíquias das vidas assassinadas, valiam-se de pedaços de seus corpos, guardavam troféus, aspectos característicos do perfil de assassino serial. Em seu próprio momento, os cartões parecem ser ódio aplicado a conta-gotas, em superfície microscópica mas adequadamente calculada, uma evidência de continuidade da prática de colecionar partes do corpo de um ser humano como prova de "justiçamento" coletivo, levado a cabo com as próprias mãos. Aberrantes como são, o preconceito, o assédio, as agressões e os crimes cometidos por essa prática de afirmar a supremacia racial, se mostram os limites da validade da classe operária como um fenômeno horizontal, também evidenciam a importância dos direitos civis e humanos - abrangentemente - aos negros, mas em específico aos homens negros braçais e pobres, que desempenhavam ocupações profissionais as mais variadas no mercado de trabalho (ou seja, como trabalhadores). Com uma relíquia ou um postal,

15 Ibidem, p. 17, 18. Para outra experiência, também fundamental na vida de Freyre (com peso decisivo sobre sua obra desde cedo), ver: PALLARES-BURKE, Maria L. $\mathbf{O}$ triunfo do fracasso: Rüdiger Bilden, o amigo esquecido de Gilberto Freyre. São Paulo: Editora Unesp, 2012.

Durante a década de 1920, o movimento negro nos EEUU lutou para que os linchamentos fossem judicialmente tratados como crimes de âmbito federal, com o intuito de diminuir ou anular a complacência das autoridades para com o terrorismo levado a cabo contra a população negra. Uso terrorismo conforme EISENBERG, op. cit., p. 103. Ver também: ALLEN, James et al. Without sanctuary. Lynching photography in America. Santa Fé: Twin Palms Publishers, 2000. 
suprematistas raciais podiam recordar e estar seguros de que tinham botado paradeiro na desenvoltura que o desempenho dos negros evidenciava, até mesmo ganhar e juntar dinheiro.

A conexão entre cartão postal e a anterior Guerra Civil estadunidense (18611865) aparece nítida em bilhete que comemora o linchamento de dois homens, não identificados, pendurados em árvores com corda no pescoço. Abaixo da imagem, o texto de um usuário da papeleta está escrito com caneta tinteiro: [eis] "o modo dos Rebeldes de lidarem com gente que não adere ao seu exército". ${ }^{16}$ Sem outras anotações, marcações, carimbo ou data, fica de todo jeito evidente que alguém justificou o assassinato de dois homens pelo fato de, na mentira contada, terem se recusado a aderir às forças rebeldes do Sul. Além disso, o autor também comete a falácia de sugerir que o Sul recrutou homens negros para a guerra contra o Norte. O que fica patente, depois disso tudo, é a conexão entre ódio racial, terrorismo, guerra pela continuidade da escravidão e linchamentos de negros, fato quantitativamente expressivo do fim da década de 1880 em diante (mais de 20 anos depois de acabado o conflito). Mais uma vez, o postal cumpre o papel do registro histórico, em múltiplas dimensões, apesar de seu pequeno tamanho. Duas ou três linhas que alguém julgou saber sobre algo revelam a micro-história das relações sociais.

Mas a supremacia racial não era fenômeno isolado. Podia aparecer - lógico vinculada à questão de gênero. Como argumenta Paula Giddings, os linchamentos não recaíam desde sempre sobre os negros. Foi em vez disso uma tradição americana que se racializou, ressalta ela. Em seu livro sobre Ida B. Wells, ela demonstra como essa jornalista, diante das suspeitas e denúncias de estupros de mulheres brancas por homens negros, descobriu que tais queixas eram em geral acesas após a descoberta de relações sexuais consensuais entre mulheres brancas e homens negros. Foi por intermédio da disseminação dos receios e da paranóia ante a presença do homem negro adulto que o linchamento se tornou uma tradição americana racializada, isto só depois de 1886. Relicário e bilhetes postais eram assim uma memorabilia de homens brancos - com apoio de suas famílias e comunidades (com apoio também de mulheres brancas, portanto) - desejosos a todo custo de manter as relações raciais, conforme pensavam, em seu devido lugar. Também eram de serventia como lugar de memória para o souvenir de que haviam feito algo de nobre, galante, e decisivo, em favor da pureza da raça branca e da mulher americana.

16 PHOTO postcard of a Southern double lynching, sem data, lote 108. Disponível em: https://www.bidsquare.com/online-auctions/cowans/photo-postcard-of-a-southern-double-lynching48096. Acesso em 24 abr. 2019. O leiloeiro esperava receber por este item cerca de 500 a 700 dólares, faixa de preço igual à da venda do CDV de Frederick Douglas. 
Contra o que chamavam de "bestialidade". ${ }^{17}$ As tradições aristocráticas de cavalheirismo, galantaria, virilidade e masculinidade estavam assim bem cuidadas. Preservados todo um modo de ser, uma cultura e uma civilização ocidentais, estavam bem combatidos os males da mestiçagem, sobretudo porque esta podia ocorrer em termos consensuais, na alcova, entre mulheres brancas e homens negros.

\section{Judiciário e reescravização}

É difícil saber se trabalhadores acorrentados foram uma tradição americana que, no pós-abolição, tal qual ocorreu com o linchamento, só passou a atingir os negros de modo preferencial a partir de um preciso momento da linha do tempo. Óbvio que, enquanto vigorou o cativeiro de africanos e afrodescendentes, trabalhadores acorrentados eram uma tradição americana racializada (extensível, talvez, aos povos originários). Então, parece claro que, se (no pós-abolição) também havia homens brancos em ferros, é um dado da realidade o fato de que todo negro escravizado havia sido colocado para trabalhar. E coação ao trabalho era exatamente o ponto do trabalho compulsório imposto a homens e jovens presos, habitualmente negros. Tal como os linchamentos, prisioneiros em ferros obrigados ao trabalho era uma imagem que caía como uma luva para quem carecia de viver a vida sob as graças dos privilégios de suprematista branco. Aqui: deter, espancar, torturar, assassinar, desmembrar corpos humanos açoitados e queimados. Não se importar com sepultamento humano e digno. Não se importar em hipótese alguma com os crimes cometidos. Ali: um homem branco armado - um agente de reforço da lei - e homens (negros) acorrentados trabalhando. Essa era outra imagem que não tinha preço e que, ainda mais, podia ser comprada barata, adquirindo-se pitoresco cartão celebrativo de uma raça suprema e socialmente dominante. ${ }^{18}$

Se os linchamentos liquidavam seres humanos, o domínio da lei os punha para trabalhar, sem apelações ou vadiagem, conforme se diz. Como dito aqui, lembra a volta dos que não foram, o passado que não passa. A lavoura, que tinha sido o último lugar a preservar o cativeiro diante, por um lado, do declínio da escravidão urbana, e, por outro,

17 GIDDINGS, Paula. Ida: a sword among lions: Ida B. Wells and campaign against lynching. New York: Amistad, 2008. p. 1-3, 211 et seq..

18 O número menor de cartões de galés e, por outro lado, a farta profusão de mensagens suprematistas em cartões comemorativos dos linchamentos (que aliás eram produzidos em maior quantidade, noticiando uma grande variedade de episódios) mostram como era celebrado com estupor o gozo da supremacia racial, mesmo sendo por intermédio de um crime. Lógico que tudo isto realça o desejo de superioridade racial, mas, em contrapartida, o número de negros sequestrados livres para o trabalho forçado é de um maciço contingente de operários infinitamente maior do que o número das vítimas de linchamentos. 
na confrontação direta com o abolicionismo e as leis emancipacionistas - sem falar de todo o tempo que durou a Guerra de Secessão -, foi, junto com as ferrovias, um dos primeiros lugares a se beneficiar com a reescravização de homens livres. Mas não era cativeiro igual à experiência histórica anterior. Douglas Blackmon chama a atenção para o fato de a obrigação ao trabalho não recair sobre toda a vida do escravizado nem ser transmitida aos seus descendentes, nascidos livres (o que não impedia de depois thes suceder o mesmo). "Foi de todo jeito escravidão", ajuíza o autor. Era um sistema pelo qual homens livres "sem culpa por crime algum, e salvaguardados em sua liberdade pela lei, eram compelidos ao trabalho sem compensação", sendo repetidamente "comprados e vendidos, e submetidos aos caprichos de senhores brancos através da aplicação regular de extraordinária coerção física". ${ }^{19}$

No entanto, como se sabe, a mesma $13^{\mathrm{a}}$ emenda que encerrou com a escravidão nos EUA também contempla a possibilidade de submeter a população carcerária, devidamente condenada em processo, ao trabalho forçado. ${ }^{20}$ Mesmo assim, podia haver mais outras brechas por onde seria tecido o fio do continuísmo do cativeiro. Em 1872, o governador Smith - uma raposa da política, mas também um veterano sulista da guerra - declarou que seu estado, a Geórgia, podia "deixar intacta toda lei [federal] dos Estados Unidos e ainda assim poderia legislar sobre o sistema de trabalho de modo a preservar o nosso velho sistema de plantation". Como Coffey anotou, Smith "recomendou aos negros evitarem a política e 'se ater ao trabalho duro e honesto"'. ${ }^{21}$ Pelo que se vê nessas divisórias raciais e de classe, os negros novamente não devem ser suspeitos de serem moleirões de vida fácil ou bandida. Isto era coisa de branco. Esses sábios homens brancos também se aproveitaram de suas queixas por indenização pelo fim da escravidão como forma de sorrateiramente fazer valer sua má vontade em pagar salários a trabalhadores, de modo que o último lugar a ser inoculado de trabalho livre foi o primeiro, no pósabolição, a reinventar trabalho por dívida, trabalho não-pago, trabalho forçado. ${ }^{22}$

As imagens impressas nos cartões postais consistem em transmissão em massa do inequívoco êxito das astúcias escravagistas dos suprematistas brancos. Contudo antes de proceder adiante com tais fontes, publica-se a seguir gravura do século XIX, sem data definida, mas que mostra homens brancos acorrentados

\footnotetext{
BLACKMON, op. cit., p. 4.

LICHTENSTEIN, op. cit., p. 17 et seq.

21 COFFEY, Walter. The reconstruction years: The tragic aftermath of the war between the states. Bloomington: Author House, 2014. p. 201.

22 Ver também: VAN DER LINDEN, Marcel. Dissecting coerced labor. In: VAN DER LINDEN, Marcel; GARCÍA, Magaly (org.). On coerced labor. Work and compulsion after chattel slavery. Leiden: Brill, 2016. p. 298 et seq.
} 
também. $E$ isto é para servir o gosto de quem está concernido com homens brancos acorrentados (havendo, note-se, um negro entre cinco brancos). Feita esta admissão, posso aqui perguntar pela existência de imagem de brancos acorrentados tangidos à força por um feitor negro. Abaixo, o feitor é branco.

\section{Figura 1}

Representation of a California chain gang.

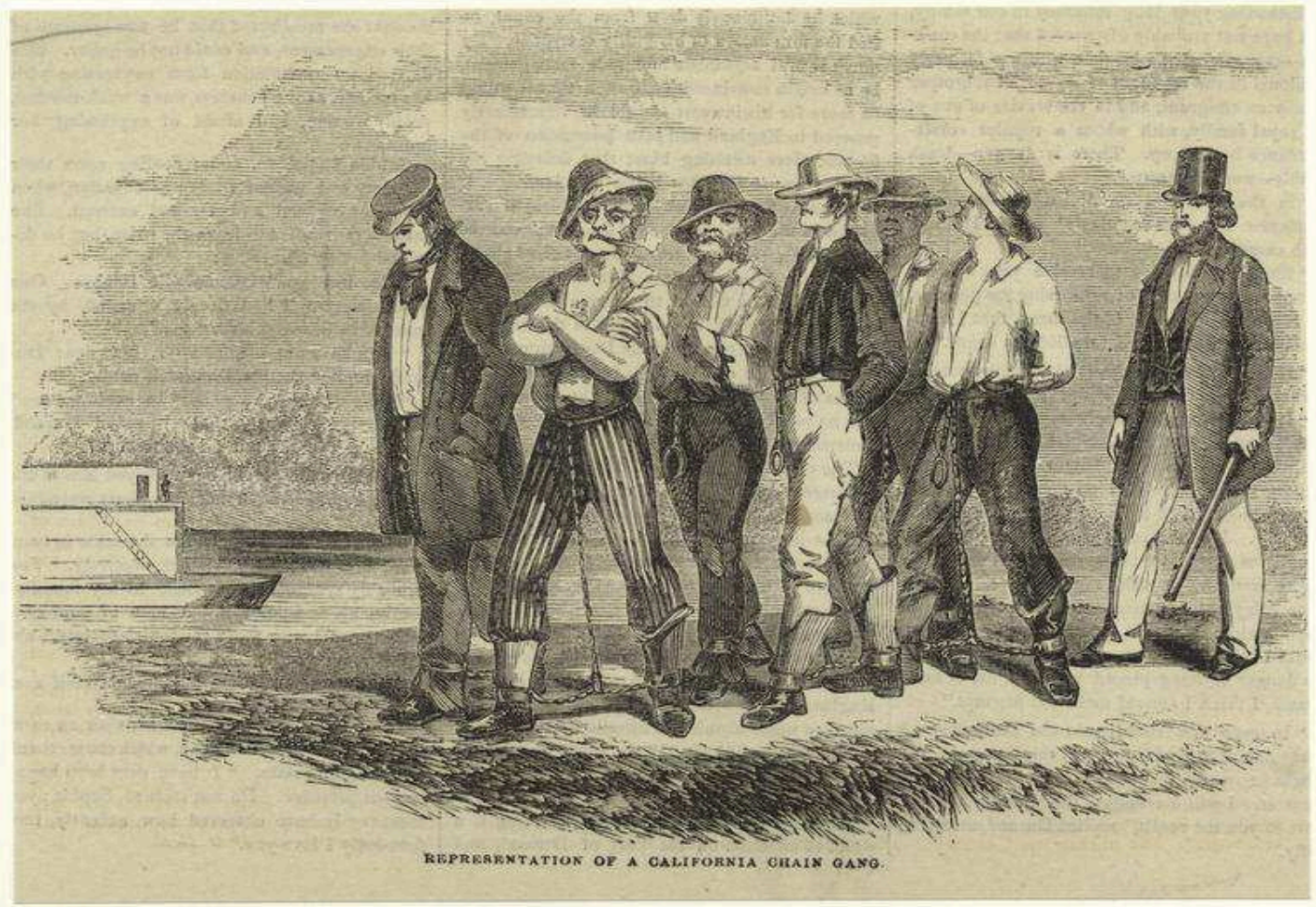

Fonte: Art and Picture Collection, New York Public Library Digital Collections. ${ }^{23}$

Meu argumento sobre a imagem acima é diverso: ela se liga ao fenômeno de um proletariado atlântico. Não serve para desmentidos do tipo brancos também foram acorrentados; as raças não existem, não tem como saber se eram brancos ou negros, mas tem como saber que não tinha racismo aí não, mas criminosos, isto sim! Aliás, se não tem mulheres aí, é porque a sociedade não era machista, cabendo aos homens os piores fardos da vida social. Bem diferentemente disso, na expansão colonial inglesa, as autoridades tiveram de confessar, contrariadas, suas dificuldades em "impor a ordem em sistemas de trabalho cada vez mais globais", vendo a razão de ser de seus problemas na presença e ação "de plebeus esbulhados, delinqüentes deportados, serviçais contratados, extremistas religiosos, piratas, operários urbanos,

23 Disponível em: http://digitalcollections.nypl.org/items/510d47e1-1d29-a3d9-e040-e00a18064a99. Acesso em: 24 abr. 2019. 
soldados, marinheiros e escravos africanos". ${ }^{24}$ Em economias tão dependentes de não pagarem trabalhadores pelo seu suor, acorrentá-los e obrigá-los ao trabalho era um recurso barato em termos de custo, e adorável em termos de lucros. Não por acaso, um regime de escravidão - só que com outro nome (camuflado até mesmo de liberdade) - transparece nos postais aqui em tela.

Segundo inscrição feita a lápis, fotografia de chain gang na Geórgia ganhou, por volta de 1895, reprodução gráfica em pouco elaborado impresso, adornada com dobradura no canto superior direito. Embora os trabalhadores não estejam acorrentados, a legenda informa: "uma turma em ferros". Há adultos e adolescentes, sendo que um deles baixou o chapéu e assim evitou ter o rosto fotografado. Há um condenado com uma picareta à frente dos demais; enfileirados atrás, portando pás, a maioria. Em pé e ao centro, na frente dos demais, um homem branco exibe a sua arma de fogo.

Figura 2

A chain gang, $1895 \mathrm{c}$.

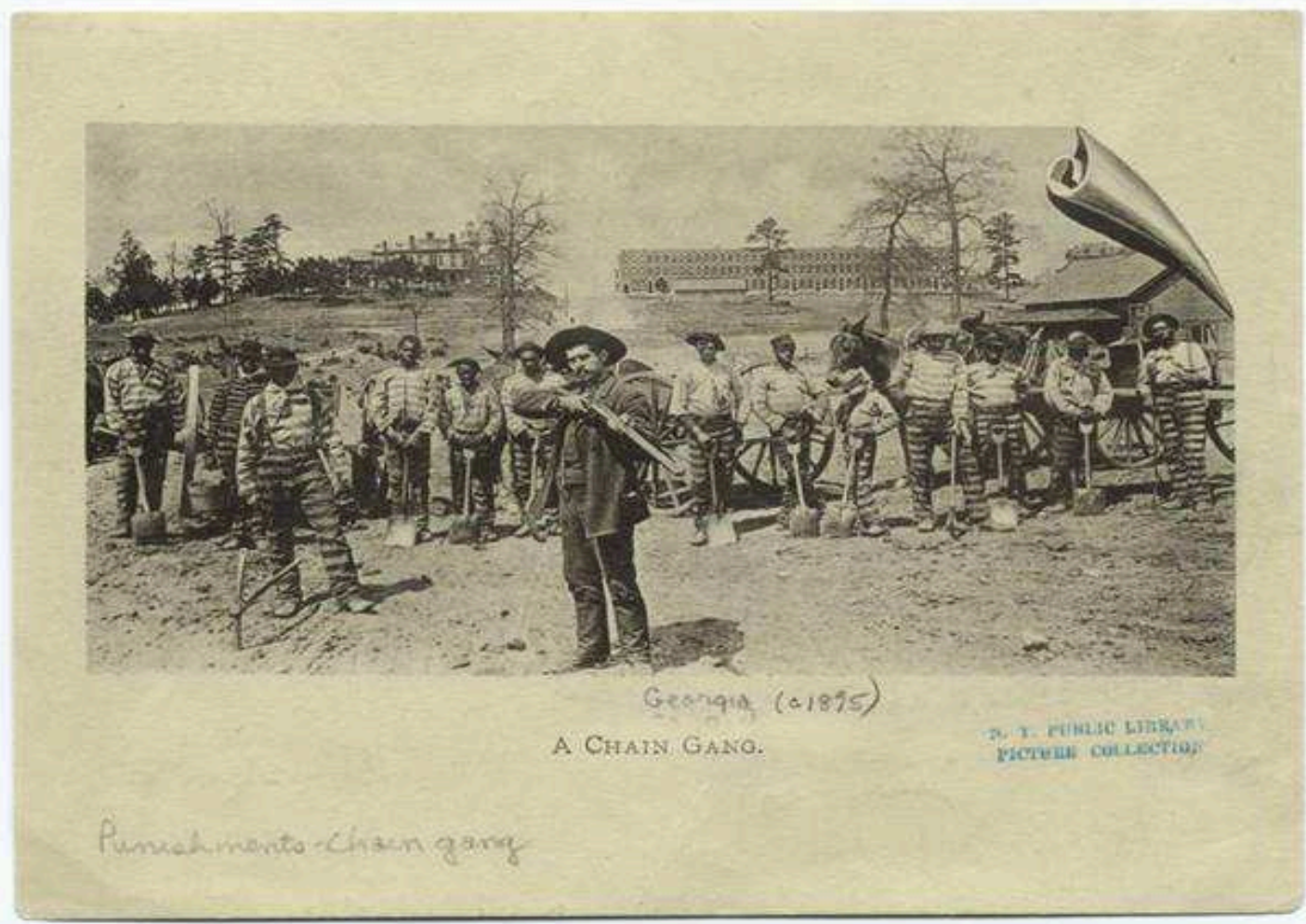

Fonte: Art and Picture Collection, New York Public Library Digital Collections. ${ }^{25}$

24 LINEBAUGH, Peter; REDIKER, Marcus. A hidra de muitas cabeças: marinheiros, escravos, plebeus e a história oculta do Atlântico revolucionário. São Paulo: Companhia das Letras, 2008. p. 12.

25 Disponível em: http://digitalcollections.nypl.org/items/510d47e1-1d2b-a3d9-e040-e00a18064a99. Acesso em: 24 abr. 2019. 
Bem mais elaborado em termos decorativos, recorrendo à técnica do cliché, bilhete postal reproduz o mesmo retrato, usa a mesma legenda - "a chain gang" - mas a coloca ao lado de uma embarcação, "a Georgia ferry", localizando as pitorescas imagens em Atlanta, estado da Geórgia. Sem data e sem reverso (nem sempre existem tais dados, nem sempre as partes dianteira e traseira estão disponíveis), P. W. M. Francis escreveu com letra esmerada "do ensolarado Sul". O lugar-comum do sol, da água e da vegetação tropical fez combinação com a mão-de-obra proletária, que aí substitui a mulher exótica objeto de desejo. A supracitada "espetacular" e planetária divisão "em fortes e fracos" estava determinada pela separação de uma "parte menor, onde o 'progresso' nascera e outra, muito maior, onde chegara como conquistador". O cartão mostra a parte fraca submetida à subtração de sua liberdade, corpo e força de trabalho pelas armas do sistema prisional. A parte forte ocupa o proscênio, o lugar mais destacado da perspectiva adotada pelo retratista. Somatória das partes em combinação, a técnica do cliché insinua a - estereotipada - feliz adaptação da raça negra ao trabalho nos trópicos. A circulação desse lugar-comum racial sugere, em segundo lugar, quem tem direito a direitos e quem está privado de cidadania. Quem aproveitou as chances do mundo livre e tem méritos está em liberdade; quem jogou tudo isso fora e seguiu os impulsos de sua raça japoneses não pedem esmola - está na prisão. A difusão global de uma empreitada conquistadora da natureza, dos territórios, das mentes, e dos corpos, implicou este assédio de aterrorizar e coagir. Sem pretendê-lo, Linebaugh e Rediker descreveram os trabalhadores da imagem abaixo: eles tinham "a pele calejada pelo trabalho contratado, pela escravidão das galés, pela escravidão das plantations, pelo transporte de condenados, pela casa de correção". ${ }^{26}$

26 HOBSBAWM, op. cit, p. 81. LINEBAUGH; REDIKER, op. cit, p. 346.

Um livro conta detalhes da detenção e fuga de um trabalhador na Geórgia da década 1920. BURNS, Robert. I am a fugitive from a Georgia chain gang. New York: The Vanguard Press, 1932. 


\section{Figura 3}

Cartão postal, 1910c.

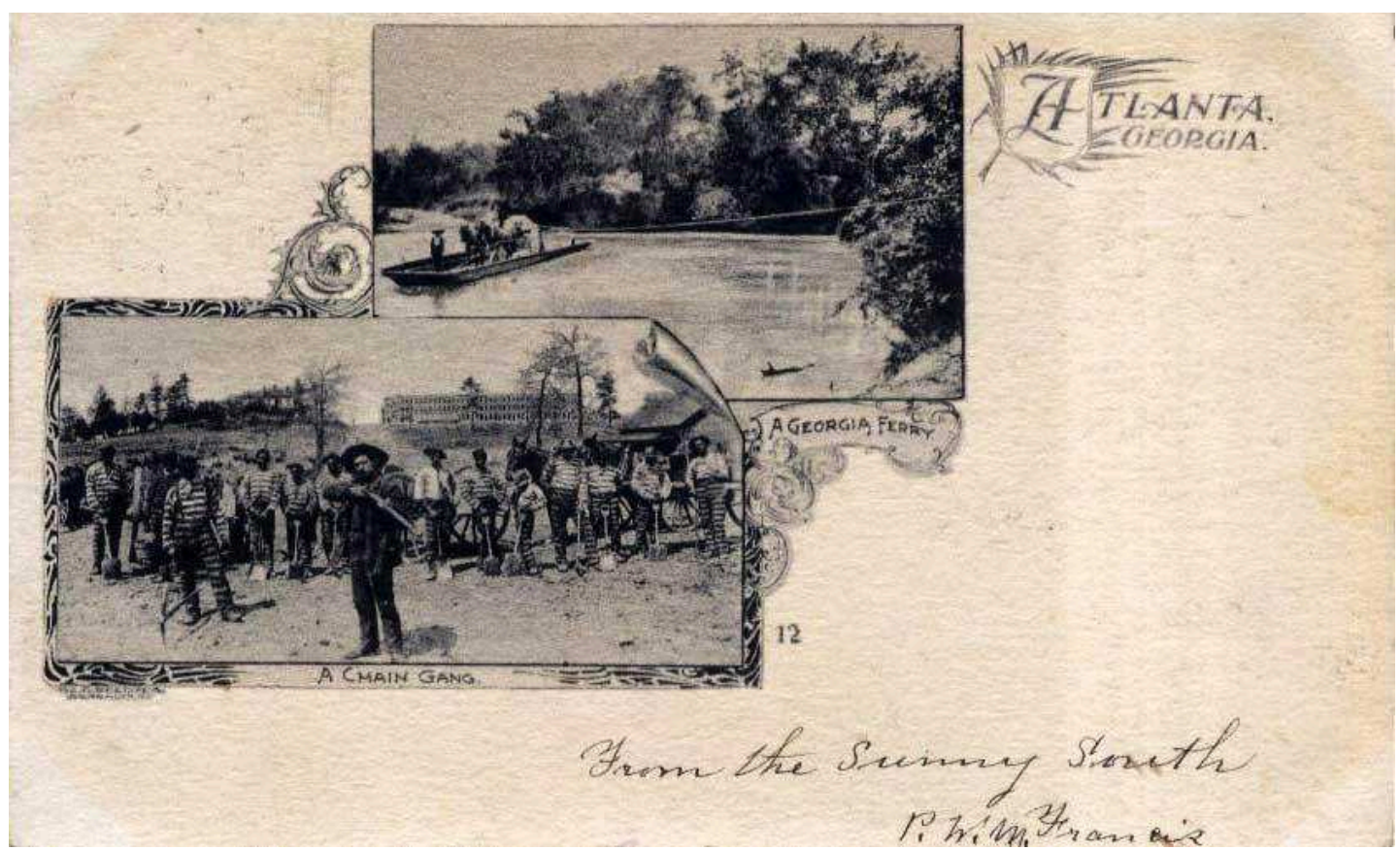

Fonte: Penny postcards. ${ }^{27}$

Datado em algum momento por volta do ano de 1912 (segundo o seu vendedor, que cobra 425 dólares), um postal oferece "imagem única" de Iredell (Carolina do Norte). "Condenados brancos e negros em uniformes listrados de prisioneiro, alguns visivelmente com correntes nos tornozelos" posam para a câmera. São negros ao menos três dos oito detentos. Um dos três fuma cachimbo e sorri; o mais jovem se acomodou elegantemente sobre a carroça. Entre os brancos, não há um que esteja visivelmente em ferros. Continua o vendedor em sua descrição: "cartão sem uso, com anotação de tinteiro no reverso". Neste, se lê: "Isso é uma parte da turma de galés do nosso município". Produzido como cartão postal, mas guardado em álbum de família, o superintendente (que é branco, precisa dizer?) parece estar armado com rifle, apoiado no ombro. Em texto cuidadoso, o vendedor busca esclarecer possíveis interessados e informa que a sentença de trabalhos forçados era um veredito padrão para fazer justiça a criminosos por "vadiagem e pequenos furtos". No estado da Carolina do Norte, ele acrescenta, era "também a punição para qualquer homem fisicamente capaz com sentença de até dez anos de prisão". Muito utilizada em obras públicas, essa mão-de-obra era deixada diretamente aos cuidados de "brutos feitores", sem que o governo se preocupasse com as condições de alojamento, alimentação, saúde e estado psíquico. Tudo isso era assunto local; e como tudo isso era tocado adiante, isso também era um assunto dos locais de bem. (Talvez, essa seja a razão

27 Disponível em: http://www.usgwarchives.net/ga/fulton/postcards/atlscn.jpg. Acesso em: 25 abr. 2019. 
de o cartão ter sido guardado em álbum de família residente em Iredell.) Não se deve deixar de observar que, por outro lado, quando xerifes vendiam detentos a gerentes de grandes empresas, estas também estavam livres para tratar os trabalhadores do jeito que achassem melhor. ${ }^{28}$

\section{Figura 4}

Iredel county roads. Cartão postal, (1912c)

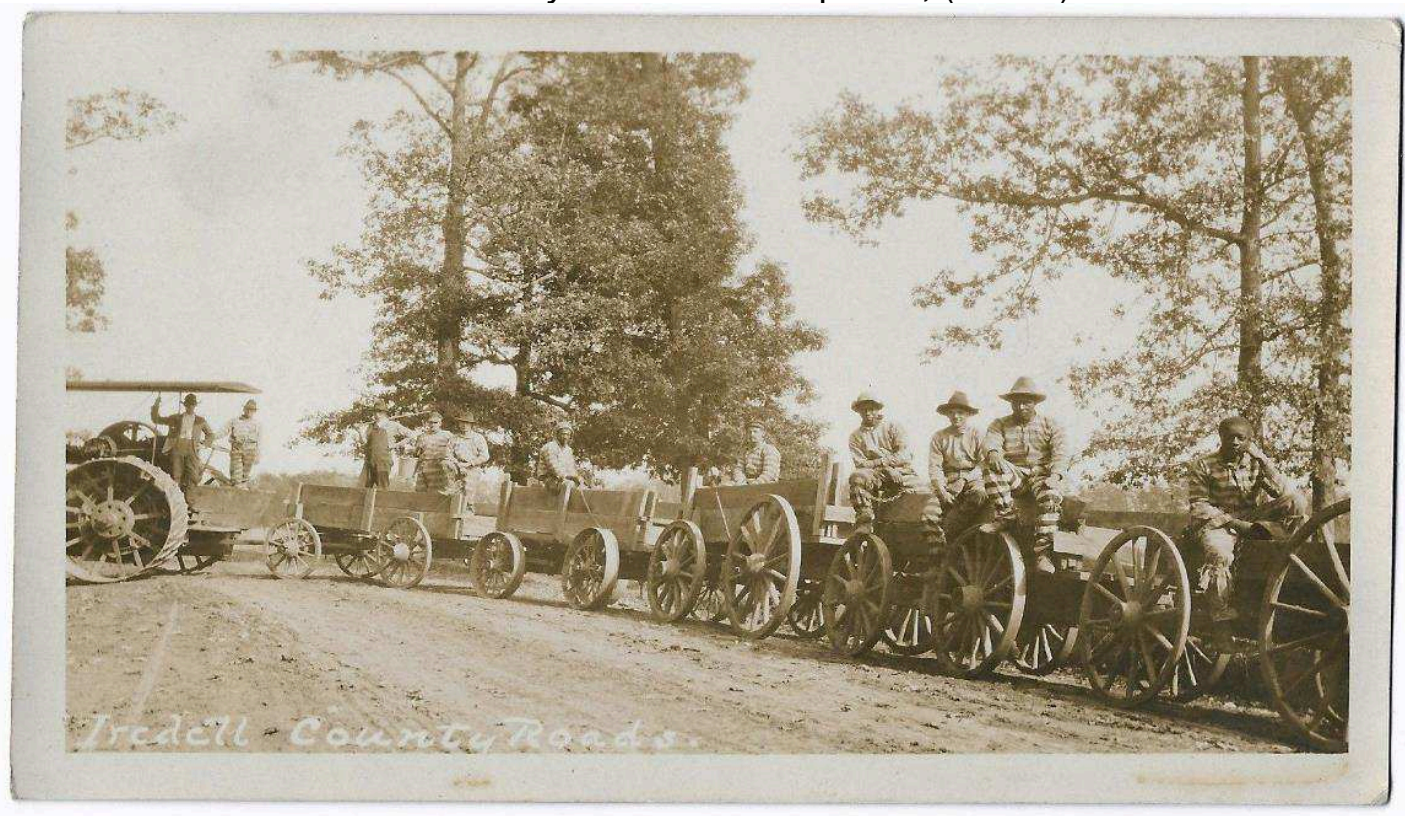

Fonte: Abe books. ${ }^{29}$

Por causa das características do artefato doravante em tela - por ter circulação mais conhecida como bilhete postal colorizado e lustroso -, a fonte abordada neste e nos próximos parágrafos até pode ser confundida com o início do século. Porém, como soía acontecer, a produção gráfica de cartões recorreu a matéria-prima fotográfica preexistente. Vale então observar que, na plataforma Wikimedia Commons, é atribuído o ano de 1892, quando teria sido feita a captura da cena que segue, pela máquina de Thomas H. Lindsey (1849-1927). Este, nascido na Virgínia, mudou-se em 1886 para Asheville, onde abriu bem-sucedida loja de retratista. Antes dessa mudança, Lindsey havia sido um jovem engajado nas forças do Sul em guerra com o Norte. Não deve portanto surpreender que ele em 1890 tenha listado essa mercadoria na "classe Z" de seu catálogo comercial. De popular aceitação, aí está tudo o que lhe reluzia como pitoresco, típico, jocoso ou exótico - tipos humanos e situações cômicas -, a exemplo das moradias das "classes baixas" (a "cabana no milharal") e fatos singulares como "compulsório" e "stripes, but no stars". "Listras, mas sem estrelas" é chistosa

28 BLACKMON, op. cit., p. 1-2.

29 Disponível em: https://www.abebooks.com/paper-collectibles/RARE-Original-1912-PRISONERCHAIN-GANG/22873069359/bd\#\&gid=1\&pid=2. Acesso em: 25 abr. 2019. 
designação que depois seria reutilizada em cartão postal; e que não aparece na carte cabinet abaixo, constando apenas no catálogo. ${ }^{30}$ Este, a propósito, por ter sido publicado em 1890, já põe a nu o erro de apontá-lo como se fosse de 1892.

\section{Figura 5}

Views of western North Carolina.

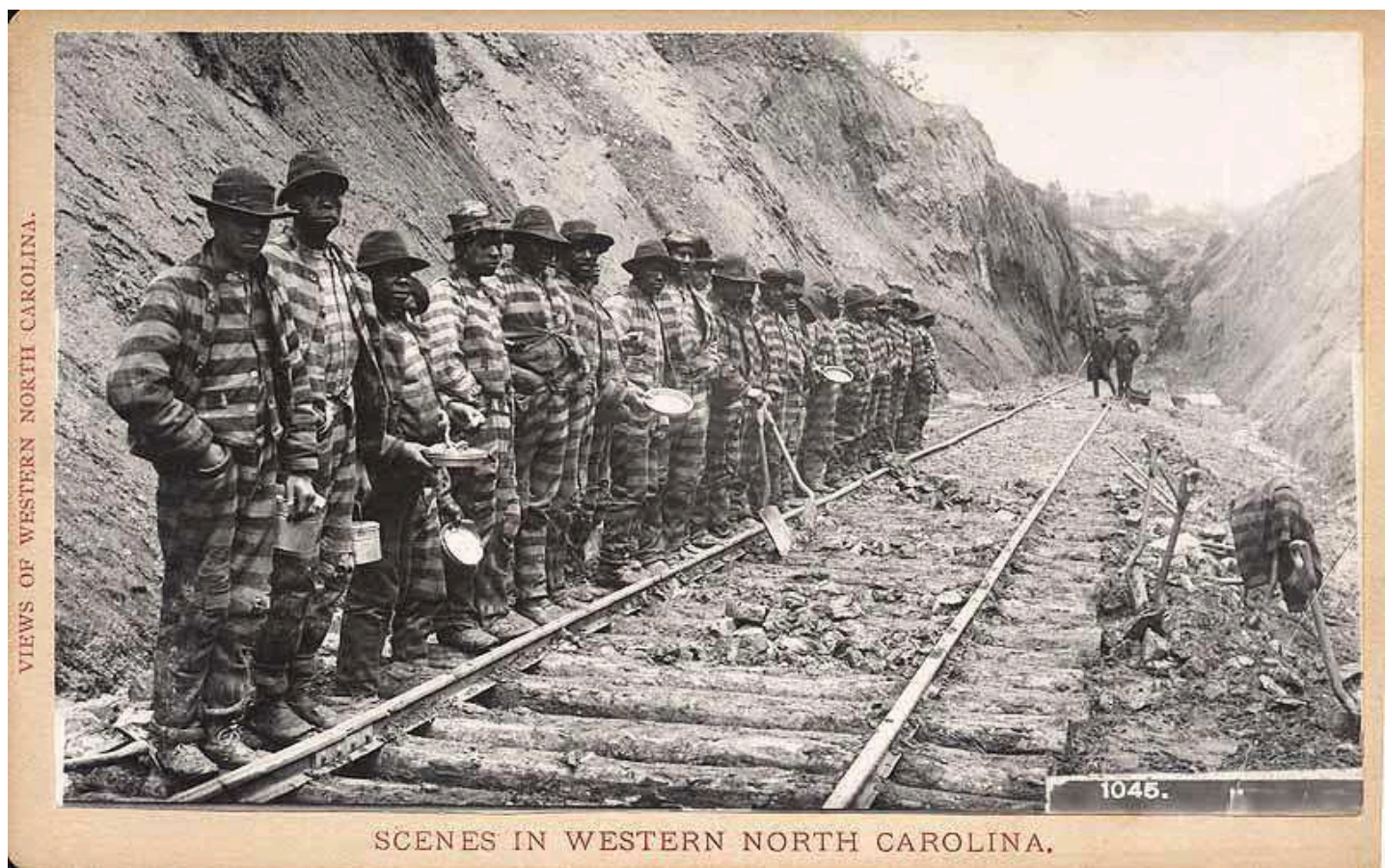

Fonte: Scenes in western North Carolina, № 1045. ${ }^{31}$

Com sensibilidade, Wallace relaciona a supracitada criação do retratista Lindsey (e sua irônica observação sobre uniformes listrados) a uma fotografia da Companhia $\mathrm{E}$, pertencente às tropas de cor das forças da União, combatentes na Guerra de Secessão. Em sua comparação, o registro imagético de soldados negros alinhados em defesa da integridade territorial e da liberdade nos EEUU constitui representação de "hombridade negra americana em sua primeira possibilidade de gênero como uma categoria significativa da vida nacional negra livre". Também ombro a ombro, a composição imagética de prisioneiros negros em "listras, mas sem estrelas" traz a lume outro uniforme que nos é familiar - de bandidos metralhas -

30 MASSENGILL, Stephen. Western North Carolina: a visual journey through stereo views and photographs. Mount Pleasant: Arcadia, 1999. p. 63.

Guide to the Lindsey and Brown Photographs. Duke University, collection guides. LINDSEY, Thomas. Lindsey's guide to western North Carolina. Asheville: Randolph-Kerr., 1890. p. 91, 92. Cartes cabinet, 1890, $\mathrm{n}^{\circ} 1063$ (cabin in the corn), 1044 (compulsory), 1045 (stripes but no stars), box 1. Lindsey and Brown Photographs, Rare Book, Manuscript, and Special Collections Library, Duke University.

31 Disponível em: https://danetteoneal.com/2012/12/18/stripes-but-no-stars-thomas-h-lindsey-1892/. Acesso em: 30 abr. 2019. 
"trágico" evento posterior ao "experimento militar na chave da hombridade negra" ${ }^{32}$ Devidamente submetidos à força da lei, negros estavam obrigados a trabalhar sob o arbitrário comando dos brancos. Mais especificamente, eu diria que eles aparecem militarmente derrotados pelo lado perdedor da Guerra Civil Americana. Se o Sul tentou se separar para preservar a sua dita civilização, apesar de vencido no conflito, essa era uma importante compensação (apesar de ter se rendido incondicionalmente), talvez porque tenha sido obrigado a aceitar abolição sem indenização aos senhores de escravos. Em boa medida, o Sul no pós-guerra assim lograva obter aquilo pelo que lutara: a coincidência entre supremacia de classe e racial. Aliás, é bom lembrar que o Sul não reconhecia nos soldados negros a figura do prisioneiro de guerra, tratando-os portanto como negros fujões que deviam ser disciplinados pela condenação ao trabalho.

\section{Figura 6}

Company E, $4^{\text {th. }}$ US Colored Infantry, Fort Lincoln. LC-DIG-cwpb-04294

(digital file from original neg.) LC-B8171-7890 (b\&w film neg.).

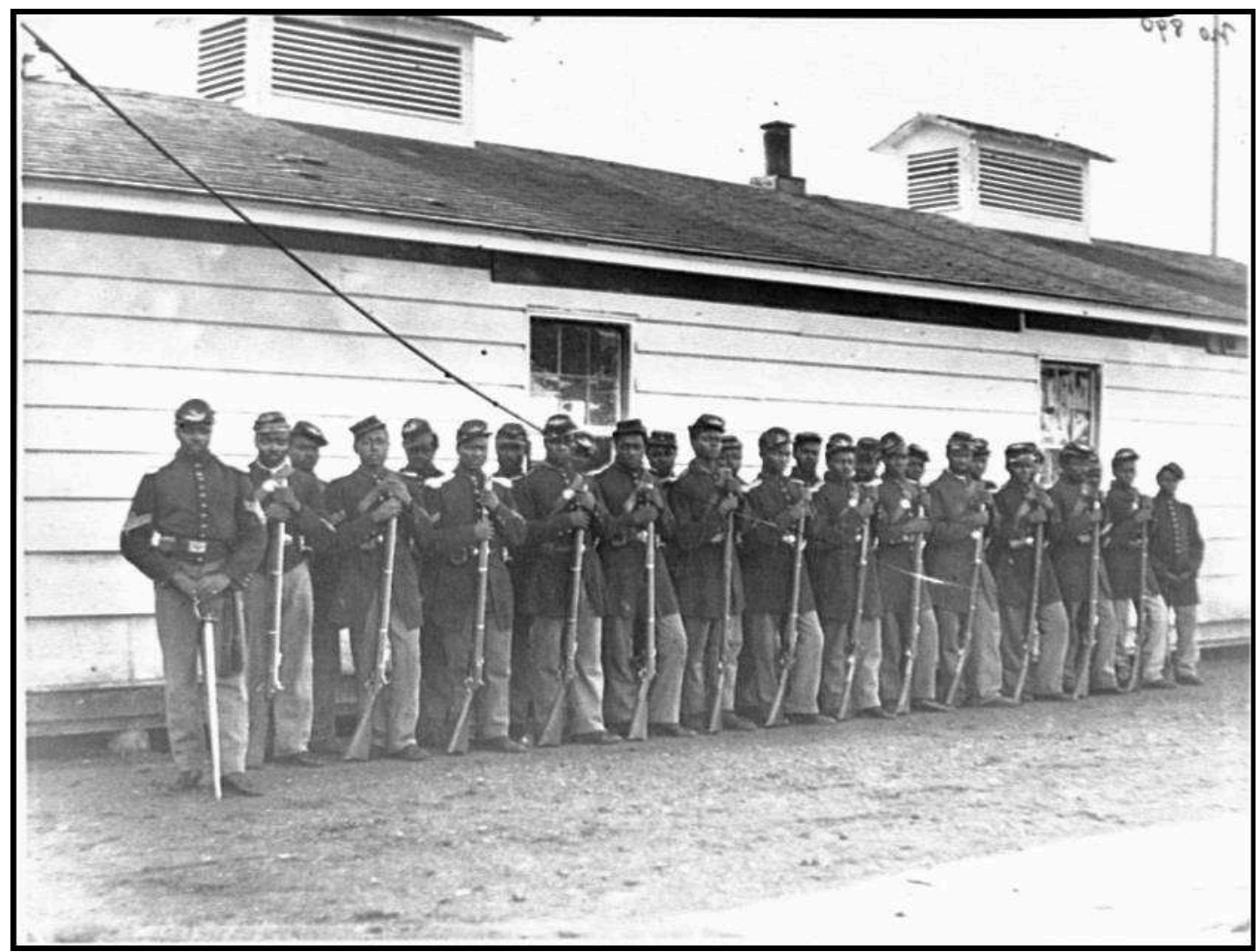

Fonte: Library of Congress Prints and Photographs Division.

32 WALLACE, Maurice. Framing the black soldier: image, uplift, and the duplicity of pictures. WALLACE, Maurice; SMITH, Shawn (org.). Pictures and Progress Early Photography and the Making of African American Identity. Durham: Duke University Press, 2012. p. 259, 260. 


\section{Em ferros, de listras, e sem estrela alguma}

Novamente segundo Wallace, tropas de cor que se renderam a comandantes sulistas em 1864, enquanto era relaxada a detenção dos oficiais brancos, foram mantidas prisioneiras em campo de concentração. Deste foram movimentadas, ao longo da guerra, para diversas obras em estradas de ferro no Alabama, Mississipi e Geórgia. Com a aproximação da vitória do Norte, quando o exército sulista bateu em retirada, os negros foram desumanamente deixados para trás. ${ }^{33} \mathrm{Em}$ quem se deparou com eles, a descoberta do campo, dos corpos, e das vítimas ainda com vida, pode ter se cristalizado certeza da mais absoluta inexistência de vínculos entre o Sul e os negros, nem mesmo os religiosos, que tanto haviam marcado essa experiência escravista. Não eram consumidores nem eleitores; tampouco eram empregados. Não eram cidadãos, não eram prisioneiros de guerra, não foram tratados como seres humanos, e talvez fossem desalmados. Não se encontrou fiapo de nacionalidade comum a supremacia branca do Sul e aos negros, de quem tanto careciam, como trabalhadores; não havia nada que ligasse a raça suprema à mão-de-obra, a não ser o seu atávico vício de usufruir da vida alheia escravizada. Desmoronado pelo esforço de guerra, o paternalismo dos senhores de escravos sangrara em hemorragia no campo de batalha, nada mais lhe restando de crédito, tanto da parte de quem o tinha inventado (os senhores) quanto da parte de quem o tinha reinventado (os escravizados). Era então uma experiência outra da combinatória das supremacias de raça e classe. Ao mesmo tempo em que patenteava a insistência dos senhores de escravos com o cativeiro, foi prova, olhando retrospectivamente, de extremo experimento de exploração e crueldade, de trabalhadores abusados, sem freios, por patrões. Essa experiência de campo de detenção ou de trabalho - arbeit lager -, que durante o conflito esteve limitada ao Sul, difundiu-se depois do conflito que acabou com o cativeiro.

Assim, no pós-guerra, o Sul suprematista, tão logo Ihe foi possível, voltou a batalhar suas causas perdidas. E quis de volta o experimento a que renunciou quando em debandada. De olho na comparação entre Brasil e Estados Unidos, foi Manuela C. da Cunha quem alertou para sobrevida das "categorias do escravismo" no mundo do pós-emancipação. Tanto "o trabalho escravo como o trabalho livre", ela sugeriu, "devem ser entendidos à luz do todo", quer dizer, o escravismo. Isso ajuda a entender os achados de outra pesquisa, de Michael Hall, sobre as duras condições encontradas pelos imigrantes livres nas fazendas de café do Oeste paulista. O apelo

33 WALLACE, op. cit., p. 261. 
constante à "violência física contra os colonos" era a contrapartida da "fraqueza de sanções ideológicas" dos fazendeiros, desdenhosos, tal qual a gentry do século XVIII inglês, de sustentar relações paternalistas. Apesar de hoje serem vistos como promotores do trabalho livre - na visão de um viajante (no início da década de 1890) -, o cafeicultor Martinho Prado, se era um burguês audacioso, também se fazia notar por sua avareza, indiferença e cinismo perante a sorte de seus empregados, que para ele nada mais eram do que uma coisa, isto é, "'instrumentos de trabalho". ${ }^{34}$

Refletindo na sua materialidade a reconciliação nacional entre o Sul e o Norte, o bilhete postal documenta a restauração do punitivismo senhorial, sobre os corpos de trabalhadores livres. Até mesmo no nortista e antigo estado de Delaware - 0 primeiro a ratificar a Constituição dos EUA -, celebraram-se os castigos públicos como um fato memorável, digno não só de registro fotográfico e circulação entre correspondentes, mas também de ser testemunhado por meninos, quer os brancos, (para aprenderem a ser homens), quer os negros (para não se esquecerem do seu lugar). Em ao menos quatro cartões diferentes entre si, veem-se pelourinhos (whipping post) em Sussex, New Castle e Kent, o que comprova a distribuição territorial da prática de punir detentos publicamente, açoitando-os. Além disso, é exibido nas imagens a serventia do sistema prisional para aplicação dos castigos. ${ }^{35}$

Sem considerações acerca da dignidade e direitos humanos, a supremacia racial tinha uma função clara: obrigar os negros ao trabalho como seres inferiores. $A$ falta de estrela no uniforme listrado é então, nada mais, nada menos, do que o esbulho da cidadania, legal expropriação empreendida por autoridades nos estados, em acordo com a Constituição. No pós-abolição, como já foi dito, a 13ª emenda contemplaria que a última noite da escravidão fosse sucedida pelo ressentido e vingativo objetivo da reescravização. Como Blackmon demonstrou, os mesmos sábios homens brancos que puseram "milhares de escravos" para construírem ferrovias e que advogaram o seu emprego em "fábricas e minas do Sul", durante os anos 1850, "foram também os primeiros a recrutar afro-americanos para o trabalho forçado, na década de 1870". Em acréscimo, o autor salienta que os anteriores "costumes de arrendamento de escravos de uma fazenda ou fábrica para a próxima" foram reacendidos por ocasião da montagem do sistema prisional de aluguel de galés, entre 1870 e 1880. Daí em diante, à medida que crescia o número de trabalhadores detidos nas prisões, cresceu - em maior proporção - o número de

34 HOBSBAWM, op. cit., p. 95. CUNHA, op. cit., p. 88. HALL, Michael. Trabalhadores imigrantes. Trabalhadores, $n^{\circ}$ 3, p. 9, 6, 1989.

35 Por motivos de força maior não é possível reproduzir os postais sem anuência do Arquivo Público de Delaware, que no entanto digitalizou diversos deles. 
homens negros na população carcerária, evidência de uma segunda tradição americana que se racializou no fim do século XIX. Essa mão-de-obra, como já comprovou Blackmon, era alugada a empresas capitalistas de todo o país, a exemplo da US Steel e subsidiárias. ${ }^{36}$ O sucesso de tal sistema estava absolutamente apoiado sobre a capacidade, não apenas de impor aos negros o preconceito racial, mas também de embargar a sua mobilidade, tolhendo a possibilidade de ir e vir, a fim de obrigar ao trabalho. Para tal, o judiciário e o sistema prisional desempenharam o papel de agentes da reescravização prevista na Constituição.

Uma vez convertida do papel albúmen do cartão cabinet para a cartolina de suporte do bilhete postal, a figura de operários em ferros, trabalhando, continuou em circulação de alta frequência, primeiro em preto-e-branco, depois em cores. Esse ritmo é perceptível até hoje: ambos os cartões estão reproduzidos na internet, são fonte de pesquisas históricas, são vendidos por revendedores, ilustram blogs e verbetes. Porém, apesar de sua expressividade e também da sugestão sarcástica quanto à condição dos trabalhadores (feita na legenda), não consegui encontrar texto expressivo em correspondência enviada pelos correios, ou anotação deixada por proprietário. Em segundo lugar, não tendo sido possível encontrar esse cartão nas coleções digitais do arquivo público da Carolina do Norte, de acordo com a NCpedia (enciclopédia na internet disposta ao público pelo governo do estado), a imagem quando em preto e branco - teria saído da gráfica, como postal, em 1915. ${ }^{37}$

"Listras, mas sem estrelas", diz a legenda que migrou do catálogo comercial à face do postal, em alusão às listras e estrelas da cintilante - spangled - bandeira dos EEUU, terra da liberdade. ${ }^{38} \mathrm{Na}$ falta de cidadania (exatamente porque cidadania era privilégio racial ou de classe, e não um direito), é realçada a posição social subalterna do trabalho duro e pesado, comandado por dois guardas. Um deles, ao fundo sobre os trilhos, porta ostensivo rifle, este sim cintilante sobre a cor escura do uniforme. Os detentos, a maioria negros, jovens e adultos, estão alinhados ao trilho. Parece ser a hora da bóia, pois com eles há pratos, além das pás e nenhuma picareta (ferramenta que talvez fosse perigosa demais para ficar nas mãos deles todo o tempo). Ao menos um curva a cabeça e, quem sabe, em ato de recalcitrância, assim deseja evitar ter o rosto capturado pelo flagrante. Aparentemente, alguém fora do enquadramento tentou

36 BLACKMON. op. cit., p. 7.

37 "Chain gang", verbete. Disponível em: https://www.ncpedia.org/chain-gang. Acesso em: 25 abr. 2019. Ver também: IRELAND, Robert. Chain gang. POWELL, William. Encyclopedia of North Carolina. Chapel Hill: University of North Carolina Press, 2006.

38 "Listras, mas sem estrelas" era "uma piada sobre homens negros no serviço militar". NELSON, Scott. Iron confederacies: southern railways, klan violence, and reconstruction. Chapel Hill: University of North Carolina, 1999. p. 170. A capa desse livro também usa o retrato tirado por Lindsey. 
animar os espíritos e elevar o moral: vários olham, com reações diferentes, na mesma direção, devolvendo com suas expressões faciais alguma interpelação que lhes foi feita, na hora do clique. Fitando a câmera, o primeiro detento, observe-se, é branco.

\section{Figura 7}

Stripes but no stars. Asheville, NC.

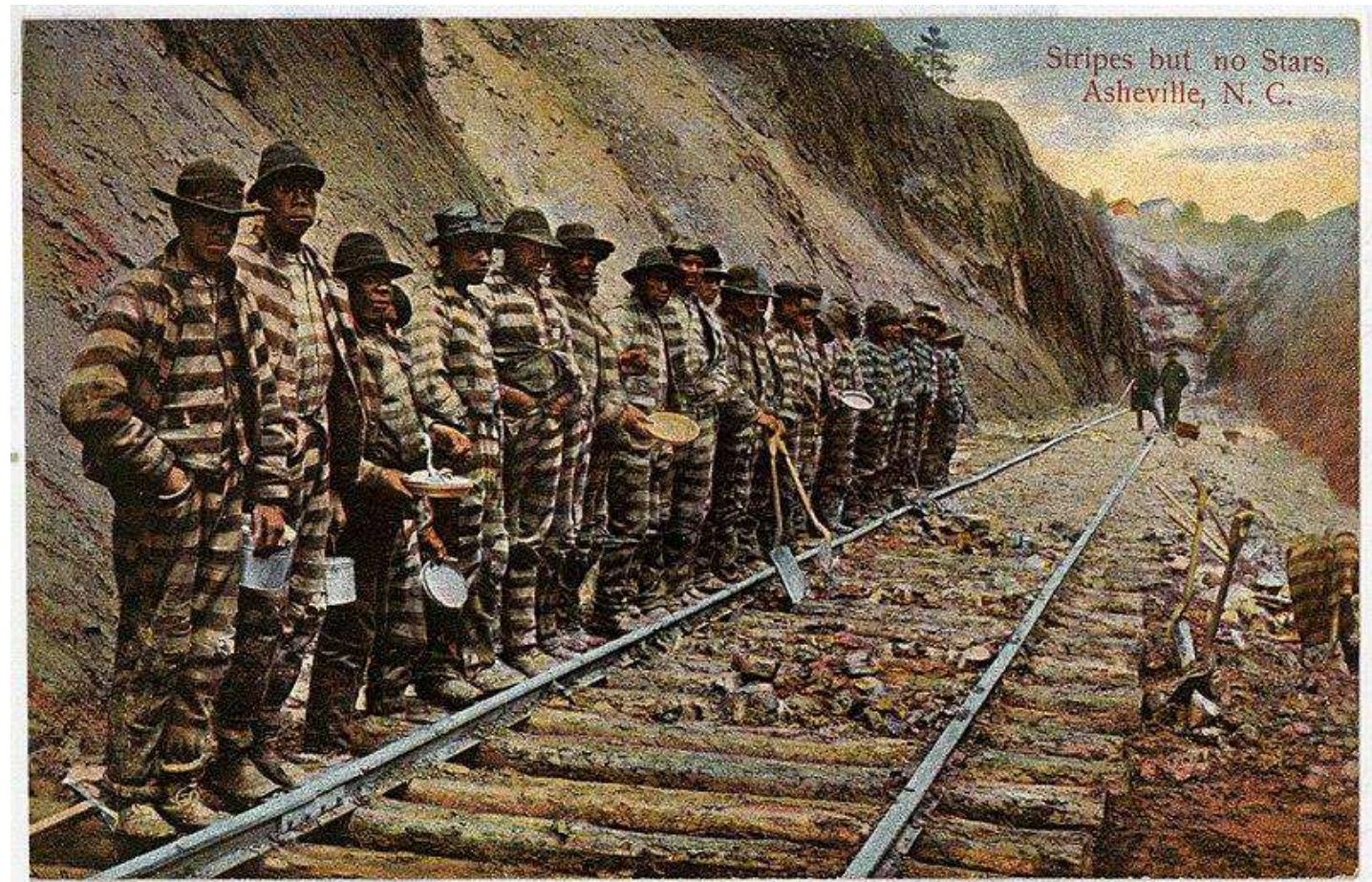

Fonte: Cartão postal, Asheville, NC. ${ }^{39}$

Se o Sul tinha menos trens rodando em seu território do que o Norte desde antes do conflito, após o seu fim, destruído pelos combates e pelo esforço de guerra, o que restou tinha de ser consertado e mantido. Ou superado com novos projetos. Nesse sentido, como afirma William Sturkey, "tal como as ferrovias, o sistema de aluguel de galés foi um produto da era moderna". Passados dois anos da aprovação em 1876 da lei do Aluguel no Mississippi, a população carcerária tinha quadruplicado e a população afrodescendente havia sido "desproporcionalmente atingida". "Entre 1865 e 1900", o autor calculou, "85\% da crescente população carcerária era negra". Enquanto uma parte era alugada a empresas privadas outra servia o poder público. ${ }^{40}$ Esse proletariado foi portanto de crucial relevo na recuperação econômica do Sul, sendo maciçamente recrutado para construir meios de transporte de escoamento da

39 Disponível em: https://commons.wikimedia.org/wiki/File:Stripes_but_no_Stars.jpg. Acesso em: 28 abr. 2019

40 STURKEY, William. Race and reconciliation on the Gulf \& Ship Island Railroad, Southern Cultures, v. 24, n 4, p. 91, 2018. Na página 93, a título de ilustração, o autor também publicou o postal de Lindsey. 
produção interna da região, continuamente marcada pela lavoura de algodão e fumo, dentre outras atividades. São essas continuidades - lavoura e trabalho forçado - que ilustram o que parece ser um desdobramento do postal supracitado, vendido avulso pela International Post Card Company. Pertencentes a outra firma (C. T. Photochrom talvez), encontrei ao menos quatro outros cartões, o que sugere serem partes de uma série. Sem pertencer a um estado específico, todos os quatro são de Dixie Land, nome pelo qual 11 estados sulistas se separaram dos EEUU, dando início à Guerra de Secessão. Três desses quatro recorrem a fotografias tiradas na penitenciária Parchman (Mississippi), "fazenda correcional famigerada por sua brutalidade", aberta - talvez cinicamente - com o intuito de ser "alternativa mais humana ao aluguel de galés às ferrovias". ${ }^{41}$

O primeiro mostra turma de galés alinhada a lavoura. Devido a questões técnicas, publica-se apenas a reprodução fotográfica do original usado para confeccionar a peça do bilhete postal.

\section{Figura 8}

Parchman Penal Firm.

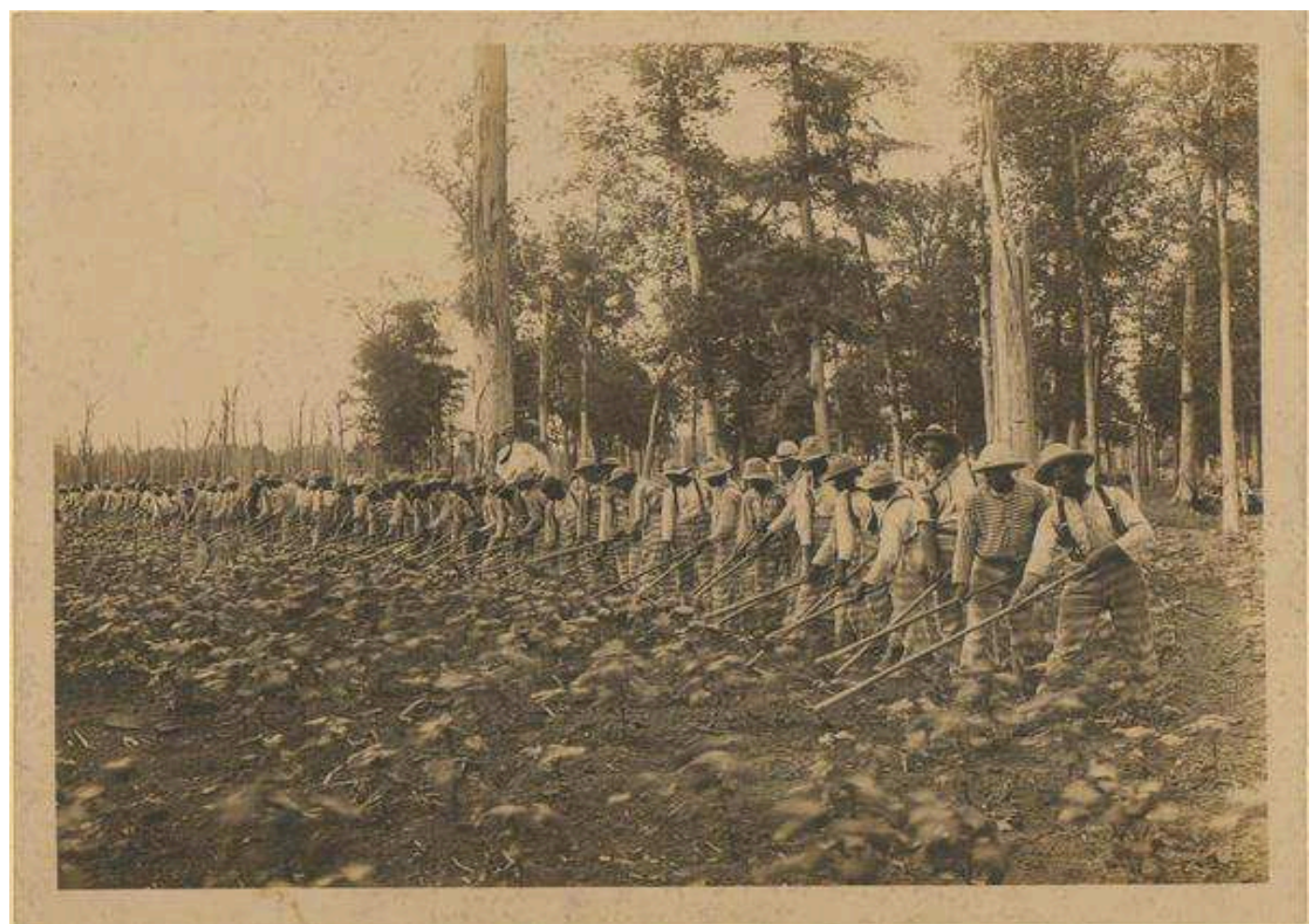

Fonte: Mississipi Department of Archives and History. Electronic archives, PI/PEN/P37.4. ${ }^{42}$

41 Ibidem, p. 101.

42 Disponível em http://www.mdah.ms.gov/arrec/digital_archives/series/parchman/detail/22823. Acesso em: 28 abr. 2019. 
O segundo cartão trata novamente do registro da mão-de-obra usada em estradas de rodagem, apresentada como pelotão em marcha unida para o serviço, num dia qualquer em Dixie Land. Em contraste com a turma disposta marcialmente ombro a ombro, o chefe branco a cavalo é conduzido candidamente por trabalhador destacado do pelotão. ${ }^{43}$ Vendido por 75 dólares, o terceiro item flagra ajuntamento de homens negros enxaguando seus uniformes (listrados, mas sem estrelas, tema da série). Como diz a legenda, era dia de lavagem num "campo de condenados" no país americano - e rebelde - de Dixie Land. O primeiro homem à esquerda exibe a calça bem lavada para retratista. Curiosamente, há um homem negro, com roupa de prisioneiro, em posição de quem carrega carabina e vigia os detentos. Mas sua roupa, como disse, é igual a dos outros, um detalhe certamente notável... Em exemplar enviado em 1918 (certamente por soldado em serviço militar em Augusta, Geórgia), o remetente diz que o tempo é quente de dia, sendo frio em geral de noite. Ao dar notícia à sua irmã de ter tido só um resfriado, informa que havia preocupação com uma gripe que grassava no local. Por causa da doença, aliás, ele não tinha liberdade de ir-e-vir, estando de resguardo na base. Provavelmente branco e seguramente bem alimentado e alojado - afora o estrelado fardamento -, o remetente, embora tenha buscado não perturbar a destinatária, a faz ver quanto as condições de saúde eram do interesse de todos (e também dele, que tinha apenas pego um resfriado).

\section{Figura 9}

Stripes but no stars, 1918.

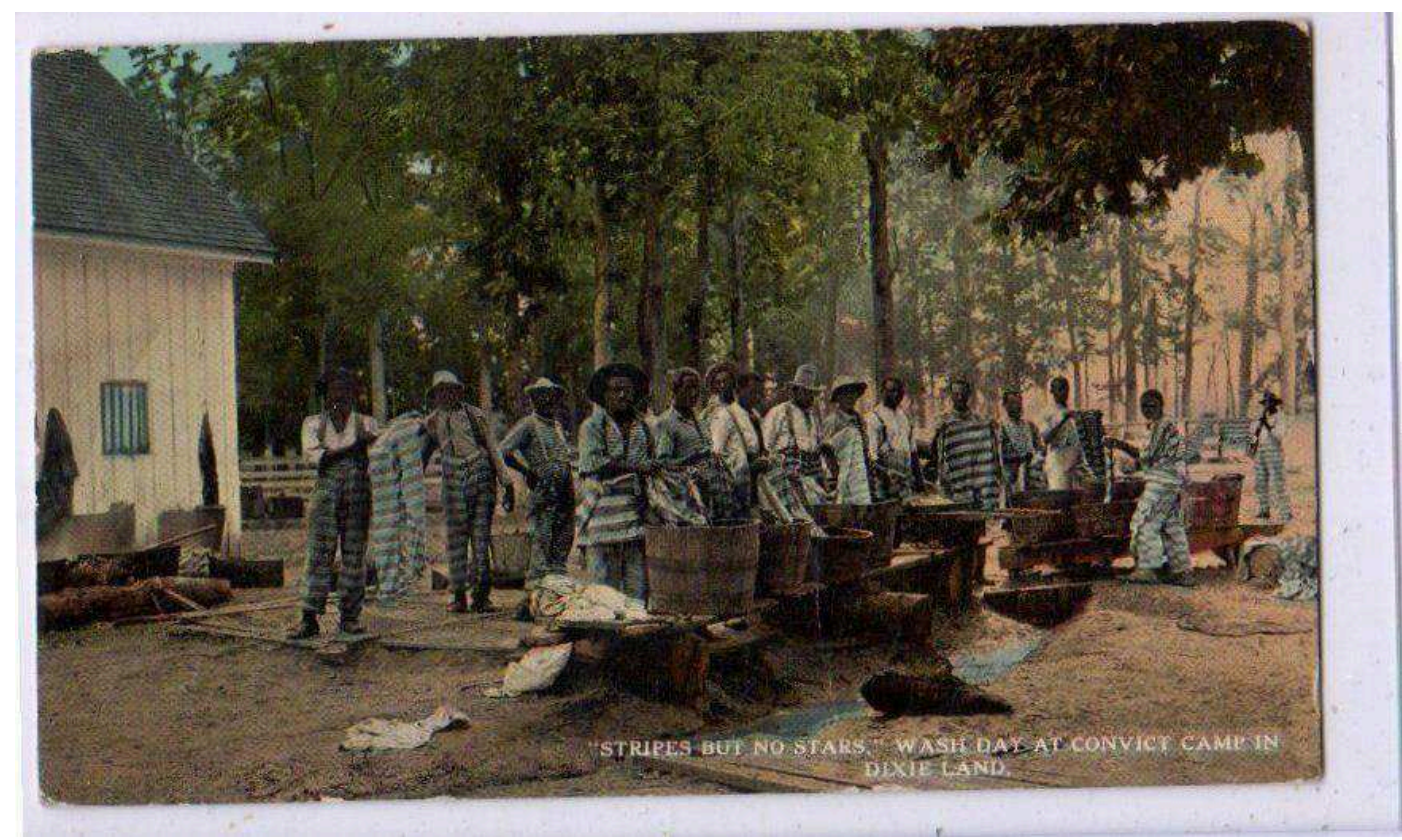

Fonte: Wash day at convict camp in Dixie Land. ${ }^{44}$

43 Não é possível reproduzir a quarta peça da série, que parece ser a única que não provém de Parchman.

44 Disponível em: https://www.ebay.com/itm/113664083055?ul_noapp=true. Acesso em: 28 abr. 2019. 
Mesmo caso da imagem 8, a cena da imagem 10 pode ser encontrada em coleção arquivística referente à unidade correcional Parchman. No arquivo, é possível saber que a coleção digitalizada tem itens datados inicialmente em 1914, o que dá a certeza de que a fotografia foi tirada entre 1914 e 1918, já que, em 1918, ela - colorizada - circulou com carimbo dos correios. Seu tempo de confecção é o da Grande Guerra (1914-1918), mas remete à Guerra de Secessão a significativa e repetida alusão ao território de Dixie Land, a terra rebelde que, por um lado, cultivava a tradição americana de obrigar os negros ao trabalho e, por outro, separou-se do país e foi à guerra contra a União, a fim de preservar toda uma civilização americana específica, típica de um lugar. Se as fotografias são da penitenciária Parchman, os cartões mostram claramente como o Sul escravagista do pós-abolição pretendia ser deixado em paz: cultivando a tradição nacional americana de obrigar os negros ao trabalho. Nesse cárcere, os condenados trabalhavam dez horas por dia e seis dias por semana. Dormiam em senzalas chamadas de "gaiolas", galpões cumpridos. Utilizada maciçamente na lavoura, a mão-de-obra masculina também era empregue na "olaria, na serraria, no descaroçador de algodão e no hospital da prisão". Havia cultos religiosos aos domingos, depois dos quais disputavam-se jogos de beisebol. ${ }^{45}$ Embora talvez fosse orgulhoso de ser auto-suficiente em tijolo e madeira - material consumido pela construção das "gaiolas" -, o punitivismo carcerário ainda não tinha descoberto os lucros dos contratos com terceirização, preferindo botar os presos para ensaboarem suas próprias roupas. O problema dessa parte específica da reescravização desses trabalhadores estava em que ninguém tirava uma gorda comissão com a higienização dos uniformes, caso fossem entregues a lavanderias. Talvez lucros fossem auferidos pela fábrica de sabão, se é que não eram feitos em Parchman mesmo.

Essa unidade carcerária era de qualquer jeito tão autoconfiante que não viu necessidade em um sistema de muros e cercas, a fim de evitar fugas. Sua localização remota e o seu vasto tamanho territorial já eram cautelas suficientes, que faziam fugitivos pensarem duas vezes. Mas essas salvaguardas não eram as únicas... Reflexo do paternalismo de senhores brancos, havia também a notável figura - conforme notei acima - dos atiradores de confiança, detentos escolhidos pelo comando da penitenciária para supervisionar os presos diretamente. ${ }^{46} \mathrm{~A}$ seguir pode-se ver um desses guardas

45 The Mississippi State Penitentiary (Parchman) Photo Collections. Mississipi Department of Archives and History. Electronic archives guide. Disponível em: http://www.mdah.ms.gov/arrec/digital_archives/series/parchman. Acesso: em 28 abr. 2019.

46 The Mississippi State Penitentiary (Parchman) Photo Collections. Mississipi Department of Archives and History. Electronic archives guide. Disponível em: http://www.mdah.ms.gov/arrec/digital_archives/series/parchman. Acesso em: 28 abr. 2019. 
mirados a dedo por seus superiores, apontado para portar arma de fogo, de grosso calibre, e estar encarregado das imediatas atividades de vigilância e punição, sobre seus pares. Na fotografia, ele está mais à direita de todos, a uma distância de quem está em posto de observação, de feitoria, e para o tiro com repetição.

Figura 10

Parchman Penal Firm.

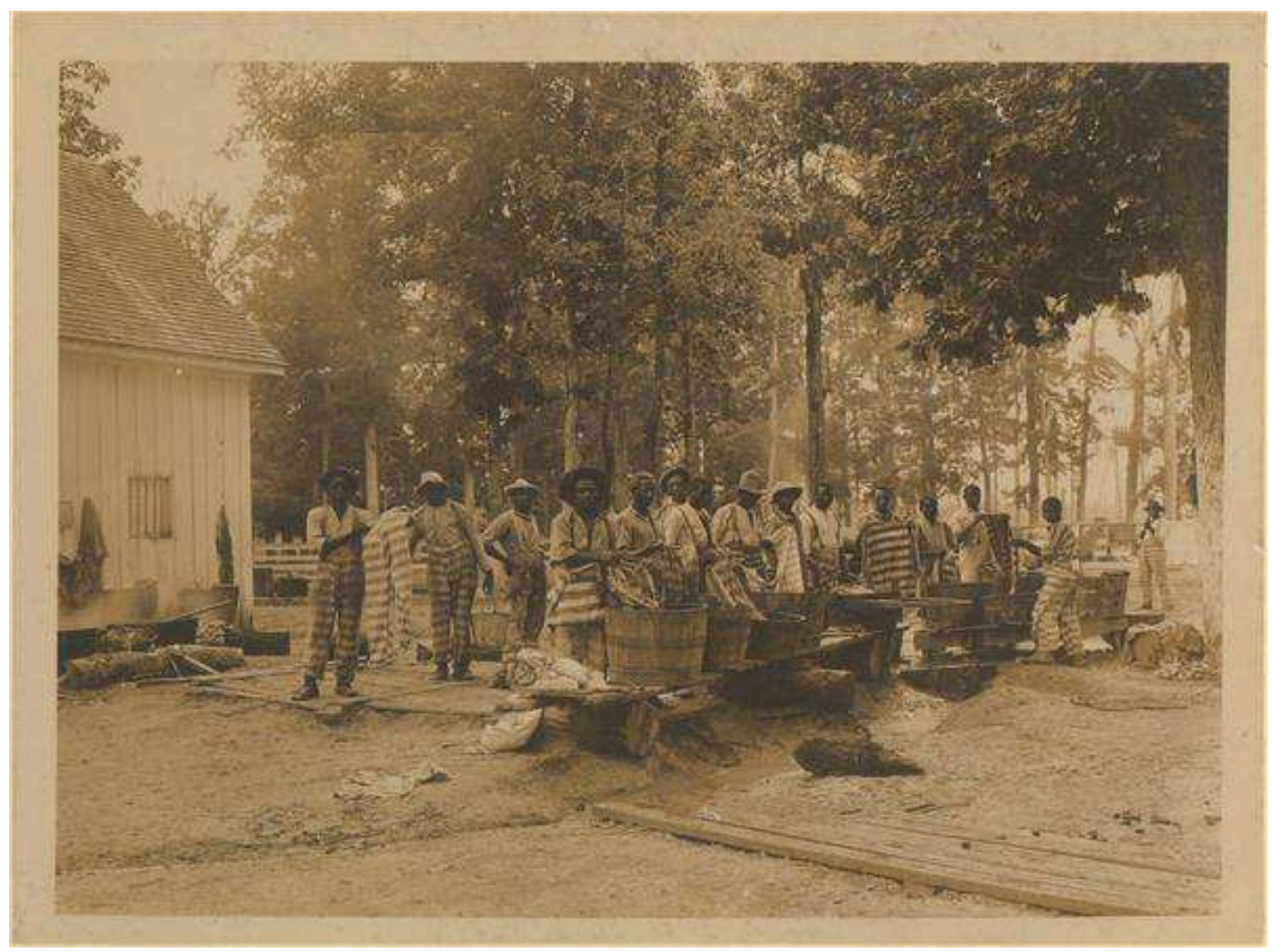

Fonte: Mississipi Department of Archives and History. Electronic archives, PI/PEN/P37.4. ${ }^{47}$

O quarto e último componente dessa série também foi originalmente preparado em Parchman e reflete o modo pelo qual o paternalismo senhorial das autoridades carcerárias pretendia entrar para a História: como um lugar bom com os negros. Os detentos estão livres em seus movimentos, mas apesar disso a legenda impressa lembra que é jantar da "turma da corrente". Não há sinal de correntes, nem dos atiradores, mas há cachorros, que podiam ser de caça, e que estão na varanda, talvez em festa com a animação do comer à mesa. Coincidentemente, na hora em que senhores brancos fazem questão não só de ser bons mas de deixar sua generosidade mui bem gravada para a posteridade, não parece haver brancos entre

47 Disponível em: http://www.mdah.ms.gov/arrec/digital_archives/series/parchman/detail/22823. Acesso em: 28 abr. 2019. 
os galés. Os senhores são bons com os negros. Colorizado com qualidade, é dia fantasioso de ditadura da felicidade em Dixie Land.

\section{Figura 11}

Chain gang at dinner in Dixie Land.

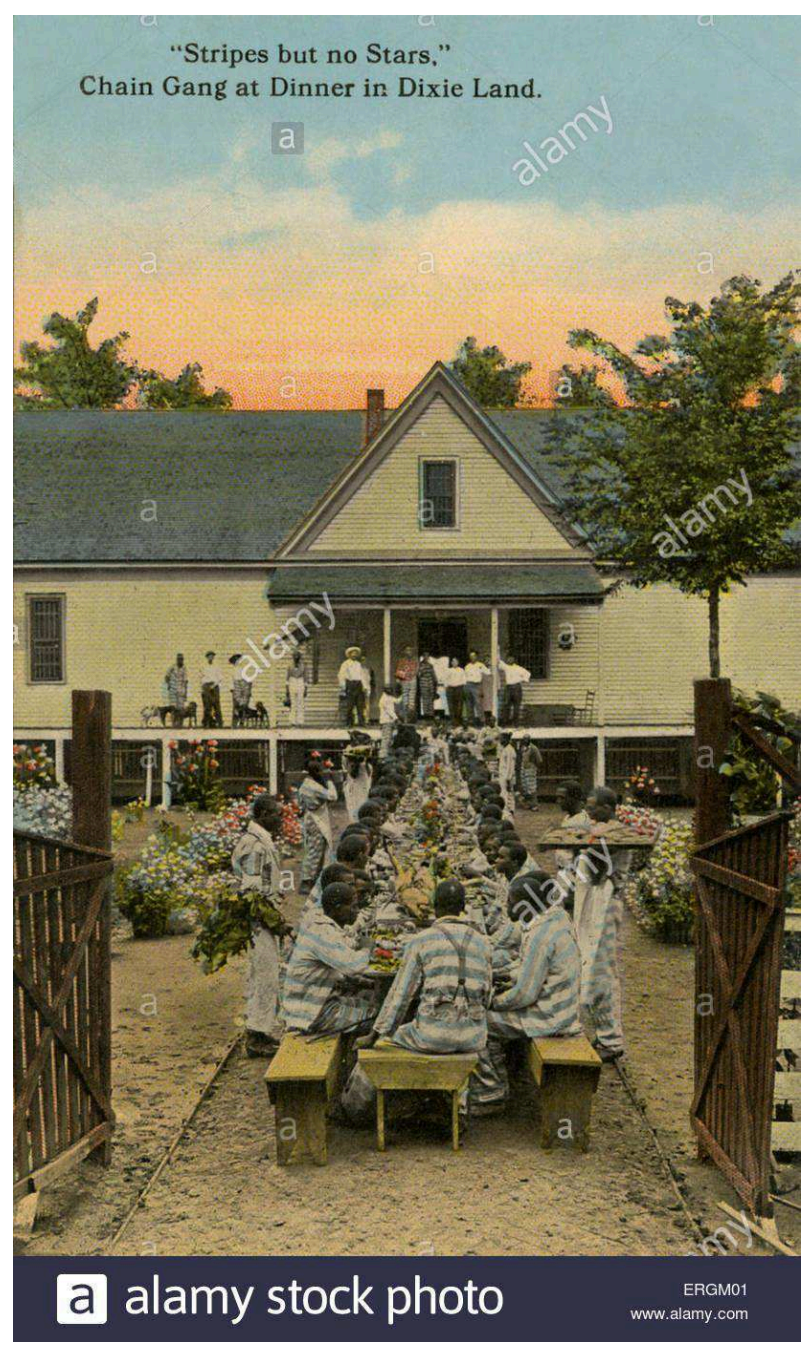

Fonte: Alamy Stock photo. ${ }^{48}$

Foi exatamente mão-de-obra barata (não só isso, mas sem pagamento e sem direitos) que a empresa Gulf \& Ship Island Railroad alugou para ostentar seus pútridos ares de iniciativa privada bem-sucedida na competitiva ordem da livre iniciativa. Em réplica, os horrores de ser operário nessa linha, Sturkey descobriu, "tal qual tantas histórias da vida dos negros no Sul", foram transmitidos em canções por décadas a fio. $O$ autor revela que The Gulf is a long railroad, além de ter sido interpretada e gravada por grupo de detentos em Parchman, é variante específica de

48 Disponível em: https://www.alamy.com/stock-photo-chain-gang-at-dinner-in-new-orleans-captionreads-stripes-but-no-stars-83345473.html. Acesso em 1 maio 2019. 
gênero onde também se encontra Long fair deal gone down, "música embalada em tradicionais canções negras de trabalho", que também menciona a linha Gulf \& Ship, tendo sido pioneiramente gravada em 1936 pelo bluesman Robert Johnson, natural do Mississippi. ${ }^{49}$

\section{Milharal}

"Não podemos ter amor sem amantes, nem submissão sem senhores rurais e camponeses", escreveu E. P. Thompson. "A relação", ele argumenta, "precisa estar sempre encarnada em pessoas e contextos reais". Classe é um "fenômeno histórico" e sua ocorrência por conseguinte pode ser demonstrada em acontecimentos sucedidos nas relações humanas. Não é então possível compreendê-la senão como uma "formação social e cultural". E classe trabalhadora é definida por homens e mulheres "enquanto vivem sua própria história e, ao final, esta é sua única definição" ${ }^{50}$

As fontes aqui analisadas são evidência do projeto nacional estadunidense de combinar, na letra da lei, as supremacias de classe e de raça. Para tal, duas tradições americanas foram racializadas: por um lado, os alvos de linchamentos passaram a ser majoritariamente homens negros e, por outro lado, a população carcerária se tornou - desproporcionalmente - negra. Os brancos, por sua vez, continuaram tanto matando quanto aprisionando. Se os linchamentos remetem à prática de terrorismo sobre a população negra, eles tinham uma função duplamente proveitosa para a raça branca: não só recaíam inclusive sobre negros que conseguiam ser economicamente bem-sucedidos, desfazendo seus êxitos, como também asseguravam que a prosperidade econômica fosse interditada à população negra. Era assim exclusividade dos brancos ter méritos, progredir, melhorar de vida, ter conforto material, poder instruir os filhos em boas escolas etc... Renda e local de moradia - e renda e endereço definem classes sociais - eram então racialmente decididos. Mas os linchamentos não deixaram de ser, ainda mais, um complemento decisivo da ação persecutória da aliança coligada entre polícia e milícia, que apanhavam no laço braços para fábricas, minas, obras e plantações, consistindo essa atividade em inequívoco atendimento das necessidades de recomposição econômica do Sul e também do próprio capitalismo estadunidense. Onde a dominação dos proprietários de terras falhasse, onde a perseguição das milícias e da polícia não vencesse, ainda

49 STURKEY, op. cit., p. 101.

50 THOMPSON, E. P. A formação da classe operária inglesa. v. I. Rio de Janeiro: Paz e Terra, 1987. p. $9,10,12$. 
poderia vingar a sanha de brancos farejando como sabujos os rastros dos caminhos de liberdade dos negros. Foi com certeza uma prática de assassinatos seriais, coletivamente sustentada, semeando o terrorismo.

Além de ferir a hombridade de soldados negros, o ato de despi-los de suas estrelas e vesti-los com uniformes carcerários transformou sonho em realidade, constrangendo-os de novo ao trabalho, eliminando suas chances de fazer escolhas, devaneio de todas as horas de ex-senhores de escravos no Brasil. Essa espoliação, que foi fotografada e vendida, quer primeiramente em cartão cabinet, quer depois no bilhete postal, é prova material da eficácia da resistência dos senhores estadunidenses ao abolicionismo e à abolição incondicional do cativeiro, além de sua sobrevivência à derrota militar. Em sua estratégia de libertação dos escravos de forma lenta, gradual e segura, os proprietários estavam dispostos a concessões sucessivas, elegendo o eito, como foi dito aqui, o último lugar a ver abolido o cativeiro. Ato contínuo, foi o primeiro lugar onde o trabalho foi camuflado de livre e, então, submetido a relações coercitivas em nada - teoricamente - compatíveis com o mundo livre da compra-e-venda da força de trabalho. Foi por isto mesmo a volta dos que não foram. Concessões sucessivas foram revertidas por reaquisições sucessivas. Uma delas foi o trabalho por dívida, cujo êxito foi depois acrescido de leis que permitiram julgamentos sumários e encarceramento em massa pelo sistema prisional, com aluguel de galés. Em síntese, a escravidão não deixou um legado para a posteridade confirmar como herdeira, ou não, de algo sinistro e horrendo que aconteceu num antigo passado. Com o fito de explorar a força de trabalho, a escravidão foi criativamente reinventada.

O Sul fez que foi embora mas não foi. Mantido derrotado pela guerra no seu país, nunca abriu mão do suprematismo de senhores de escravos, pedra fundamental - pedra filosofal, e também pedra talismânica - de toda uma civilização que se declara "Ocidental" e se queixa de estar ameaçada de extinção, dada a sua contínua neurose quanto a inimigos externos e internos. Foi noutro sentido a volta dos que não foram porque o Sul suprematista se empenhou em tratar os trabalhadores negros do mesmo modo como foi tratado pelo Norte, quando este entrou em guerra com Dixie Land, querendo impedir a separação. Ardorosamente, a população negra quis o divórcio e também queria ser deixada em paz, desejando igualmente a maximização da sua cidadania recém-conquistada. Mas como não há submissão sem senhores e trabalhadores, os suprematistas não os deixaram desmanchar a relação e então os envenenaram; primeiro com o endividamento, depois com o encarceramento. A mobilidade dos negros foi respondida com a busca de sua imobilização. Invejosos, ao perceberem a desenvoltura e os rumos dos 
trabalhadores em sua liberdade, capazes até mesmo de acumular dinheiro, suprematistas brancos entraram no pesadelo paranóico que seu mundo local e sua cultura específica iriam entrar em extinção. Era preciso impedir que os negros se despregassem desse apodrecido tecido social que era Dixie Land, pois, sem a subordinação, restaria quase nada para o suprematismo.

É na popular rubrica "classe Z" do retratista Thomas Lindsey que se encontra prova indiciária, em sua materialidade, do projeto alternativo dos trabalhadores no pós-abolição. Sem tê-lo encontrado reelaborado em cartão postal, o cartão cabinet enfoca uma mulher adulta, de cabelo grisalho e pé descalço. Sem trazer algo que seja exclusivamente um adorno, seu porte não é negligente; tem, antes, elegante linguagem corporal. Como talvez não seja uma residência, a cabana possivelmente fosse uma guarida para guardar ferramentas, insumos e outras coisas ao abrigo do clima e dos animais, talvez servindo também para estocar frutas, armadilhas de caça, sementes, mudas ou parte da colheita. Sem dúvida, podia servir para o pouso e a pausa dos trabalhadores. Construída com toras de árvores - e quase nenhuma tábua -, deu trabalho fazer e foi feita para durar. O que está claro em volta da mulher é o milharal. Certamente isso era do seu agrado. Lindsey sintetiza a representação da realidade que ele flagrou como retratista exatamente com essas palavras "cabana no milharal". Ele, porém, se imprimiu no verso do cartão uma longa descrição da série The land of the sky (a terra do céu), referência alguma fez ao retrato.

Como foi aqui dito desde o início, os planos dos negros no pós-abolição quanto à sua sobrevivência na área rural passavam por continuar fazendo o que já sabiam fazer muito bem. Com a vibrante energia de suas canções de trabalho, lidar com a terra era uma dessas coisas. Nesse sentido, a pequena produção agrícola e a pequena propriedade figuravam em suas intenções. Antes do sonho da propriedade, o objetivo concreto era o da segurança alimentar, quer dizer, ter o que comer e, em acréscimo, ter o que vender, para depois ter como comprar. Com sementes crioulas, produção agrícola de alimentos e comércio: duas características notáveis na história dos trabalhadores escravizados e libertos, elemento de continuidade de sua experiência histórica, entre o cativeiro e o pós-abolição. Este era um jeito duro de trabalhar, honesto de viver e progredir. Os trabalhadores queriam fazer o seu dinheiro e consumir os bens do progresso material. Com certeza havia outros jeitos de trabalhar e ganhar a vida, com certeza também podiam ter outros planos. Na terra do céu, a cabana no milharal era segurança: terra, trabalho e liberdade. 


\section{Figura 12}

Views of western North Carolina. The land of the sky, no 1036, 1890c.

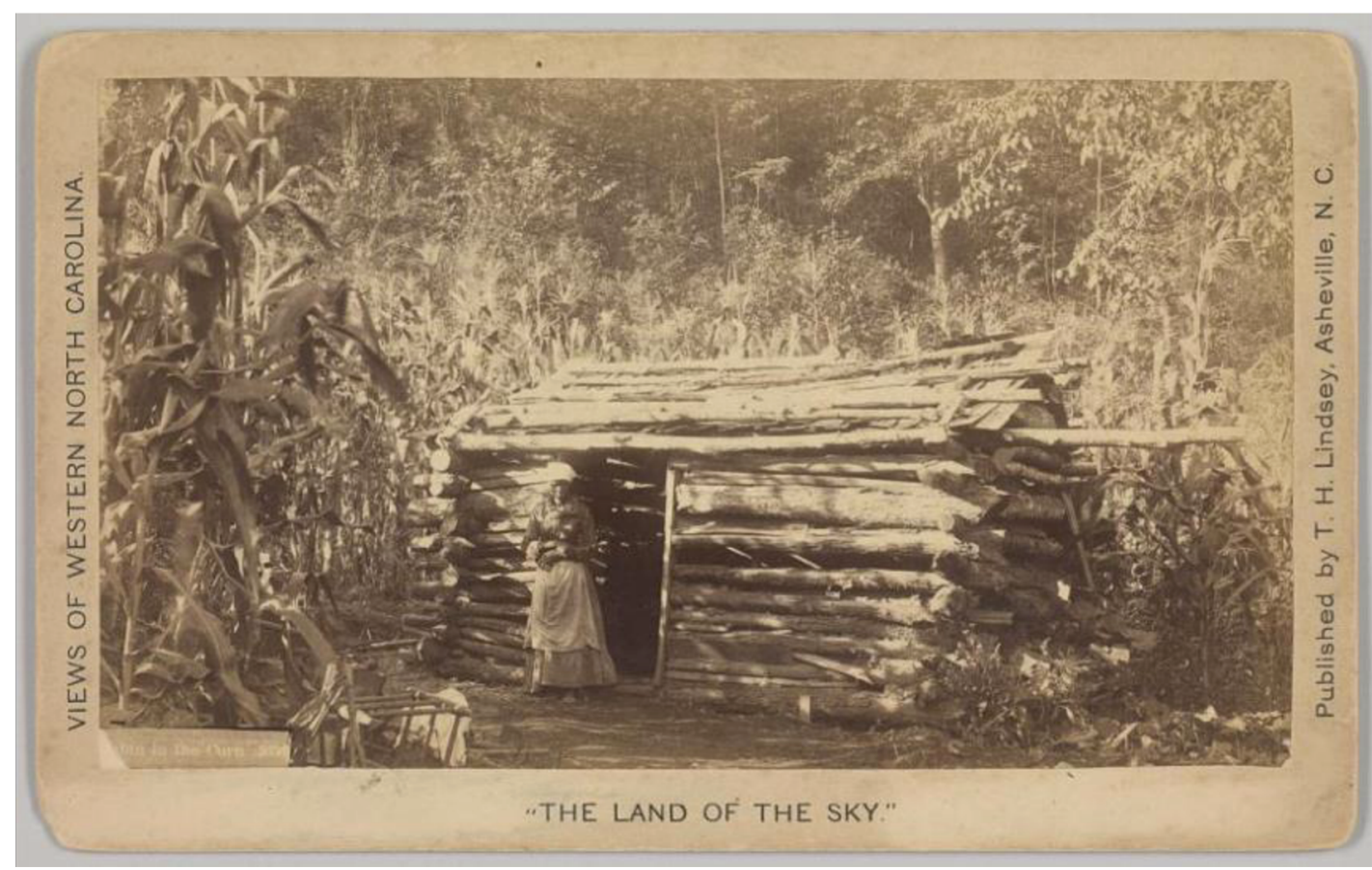

Fonte: Collection of the Smithsonian National Museum of African American History and Culture, gift from the Liljenquist Family collection, 2016.166.14. ${ }^{51}$

Recebido em 27/05/2019

Aprovado em 11/06/2019

51 Disponível em: https://nmaahc.si.edu/object/nmaahc_2016.166.14?destination=explore/collection/ search\%3Fedan_q\%3D\%252A\%253A\%252A\%26edan_fq\%255B0\%255D\%3Dp.edanmdm.indexe dstructured.name $\% 253 \mathrm{~A} \% 2522 \mathrm{Lindsey} \% 252 \mathrm{C} \% 2520$ Thomas $\% 2520 \mathrm{H} . \% 2522 \% 26 \mathrm{edan}$ local\%3D 1\%26op\%3DSearch. Acesso em: 3 maio 2019.

Revista Mundos do Trabalho | Florianópolis | vol. 11 | 2019 | p. 1-31 